\title{
Radioactive Particle Resuspension Research Experiments on the Hanford Reservation
}

by

\author{
G. A. Sehmel
}

February 1977

This work was done for the Energy Research and Development Administration under Contracts EY-76-C-06-1830 and E(45-1)-1830 with Battelle, Pacific Northwest Laboratory and under Contract E(45-1)-2130 with Atlantic Richfield Hanford Company 


\title{
NOTICE
}

This report was prepared as an account of work sponsored by the United States Government. Neither the United States nor the Energy Research and Development Administration, nor any of their employees, nor any of their contractors, subcontractors, or their employees, makes any warranty, express or implied, or assumes any legal liability or responsibility for the accuracy, completeness or usefuiness of any information, apparatus, produc: or process disclosed, or represents that its use would not infringe privately owned rights.

\author{
PACIFIC NORTHWEST LABORATORY \\ operated by \\ BATTELLE \\ for the \\ EVERCY RESEARCH AND DEVELOPMENT ADMINISTRATION \\ Under Contract EY-76-C-06-1830
}

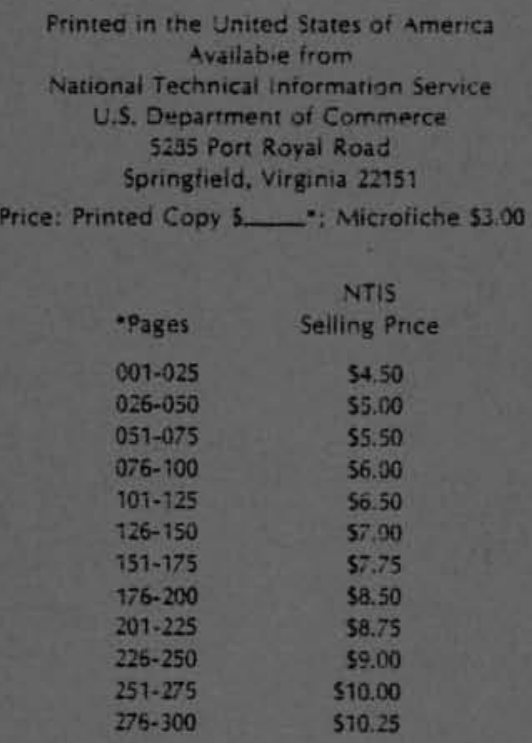


BNWL-2081

$U C-11$

RADIOACTIVE PARTICLE

RESUSPENSION RESEARCH

EXPERIMENTS ON THE

HANFORD RESERVATION

by

G. A. Sehmel

February 1977

This work was done for the Energy Research and Development Administration under Contracts EY-76-C-06-1830 and $E(45-1)-1830$ with Battelle, Pacific Northwest Laboratory and under Contract E(45-1)-2130 with Atlantic Richfield Hanford Company.

\section{BATTELLE}

Pacific Northwest Laboratories

Richland, Washington 99352 
$\underline{\text { SUMMARY }}$

Experiments were conducted from 1972 to 1975 at several Hanford Reservation study sites to determine whether radioactive particles from these sites were resuspended and transported by wind and to determine, if possible, any interrelationships between wind speed, direction, airborne soi 1, and leve1s of radioactivity on airborne particles. Samples of airborne particles were collected with high volume air samplers and cascade particle impactors using both upwind and downwind air sampling towers. Most samples were analyzed for ${ }^{137} \mathrm{Cs}$; some samples were analyzed for ${ }^{239} \mathrm{Pu},{ }^{238} \mathrm{Pu}$ and ${ }^{241} \mathrm{Am}$; a few samples were analyzed for ${ }^{90} \mathrm{Sr}$. This report summarizes measured air concentration ranges for these radionuclides at the study sites and compares air concentrations with fallout levels measured in 300 Area near the Reservation boundary.

Study results indicated that:

1) Airborne concentrations increased with wind speeds to the 1.0 to 1.5 power for the data shown.

2) Maximum measured airborne concentrations for all radionuclides were substantially less than the maximum permissible airborne concentrations $\left(\mathrm{MPC}_{40 \mathrm{hr}}\right)$ for uncontrolled areas, but were greater than fallout levels.

3) The weathering half-life, or time required for airborne concentrations to decrease by one-half, is much greater than previously reported in the literature: 5 months or longer rather than 30 to 45 days. 


\section{CONTENTS}

SUMMARY

LIST OF FIGURES.

LISTOFTABLES .

INTRODUCTION .

CONCLUSIONS .

STUDYSITES .

U-POND AND BC-CRIB AREAS

OTHER RESUSPENSION STUDY SITES . . . . . . . . . . . . 6

RESUSPENSION EXPERIMENTS . . . . . . . . . . . . . . . . . . . . . 7

EXPERIMENTAL CONDITIONS . . . . . . . . . . . . . . . . . 7

BC-CribArea . . . . . . . . . . . . . . . . . . . . . 9

U-Pond Area. . . . . . . . . . . . . . . . . . . 9

Z-19Ditch . . . . . . . . . . . . . . . . . 9

S-16 Area . . . . . . . . . . . . . . . . . 9

Gable Mountain Pond . . . . . . . . . . 10

Hanford Meteorological Station Tower . . . . . . . 10

SAMPLER LOCATIONS . . . . . . . . . . . . . . . . 11

SAMPLING WITH RESPECT TO WIND DIRECTION . . . . . . . . . 11

SAMPLING AS A FUNCTION OF WIND SPEED . . . . . . . . . . 11

RADIOCHEMICAL ANALYSES. • • • . . . . . . . . . 11

SITE FOR FALLOUT LEVEL COMPARISON. 


\section{FIGURES}

1 Locations of Resuspension Sites. . . . . . . . . . . . 4

2 Airborne Radionuclide Concentrations as a Function of Wind Speed West of U-Pond in Relation to Fallout Levels in 300 Area . . . . . . . . . . . . . . . . 14

3 Airborne Radionuclide Concentrations as a Function of Height East of U-Pond. . . . . . . . . . . . . . 16

4 Range of Downwind Airborne ${ }^{137} \mathrm{CS}$ Concentrations at Resuspension Sites Compared to Fallout Levels.

5 Range of Downwind ${ }^{137}$ Cs Concentrations on Airborne Soil at Resuspension Sites. . . . . . . . . . . . . . . 18

6 Range of Airborne Pu Concentrations at Resuspension Sites Compared to Fallout Levels . . . . . . . . . . 19

7 Range of Pu Concentration on Airborne Solids at Resuspension Sites. . . . . . . . . . . . . . 21

8 Range of Airborne ${ }^{241}$ Am Concentrations at Resuspension Sites Compared to Fallout Levels. . . . . . . . . . . . 21

9 Range of ${ }^{241}$ Am Concentrations on Airborne Solids at Resuspension Sites... . . . . . . . . . . . . 22

10 Airborne Particle Volume Distribution. . . . . . . . . 31

\section{$\underline{\text { TABLES }}$}

1 Summary of Experimental Parameters. . . . . . . . . . 8

2 Ratio of Maximum Measured Airborne Concentrations to MPC $C_{\text {air }}$. 25

3 Concentrations of Radionuclides in Hanford Ground Surface

Solid Samples Reported in Literature.. . . . . . . . . . 26

4 Ratio of Airborne to Ground Surface Radionuclide Concentrations per Gram of Solids . . . . . . . . . . . 26

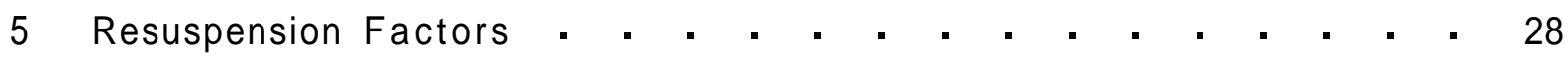

6 Calculated Airborne Concentrations from Airborne Solids Concentrations and Surface Contamination.

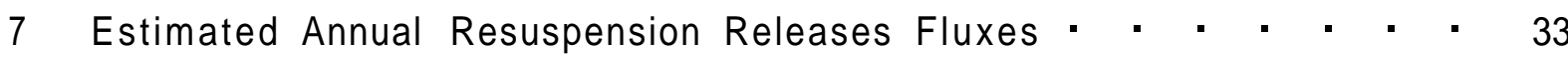




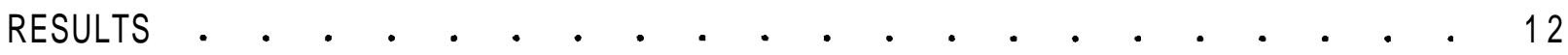

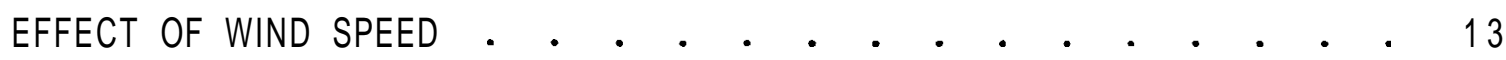

AIRBORNE RADIONUCLIDE CONCENTRATION AS A FUNCTION

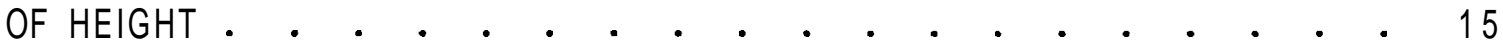

CESIUM- 137 CONCENTRATIONS . . . . . . . . . . . . . . 16

PLUTONIUM CONCENTRATIONS

AMERICIUM-241 CONCENTRATIONS . . . . . . . . . . . . 20

DISCUSSION OF RESULTS . . . . . . . . . . . . . . . . . 23

RELATIVE AMOUNTS OF RADIONUCLIDES ON PARTICLES

RESUSPENDED . . . . . . . . . . . . . . . . . . 23

AIRCONCENTRATIONS IN RELATIONTOMPC'S . . . . . . . . . 24

RADIONUCLIDES CONCENTRATIONS ON AIRBORNE AND GROUND SOLIDS . . 25

RESUSPENSION FACTORS . . . . . . . . . . . . . . . 27

PREDICTED AIRBORNE RADIONUCLIDES CONCENTRATIONS FROM

AIRBORNESOLIDS . . . . . . . . . . . . . . . . 29

RESUSPENSION RELEASE FLUXES. . . . . . . . . . . . . . 29

SUGGESTED FUTURE RESEARCH . . . . . . . . . . . . . . . 34

$\begin{array}{ll}\text { REFERENCES } & 37\end{array}$ 


\section{$\underline{\text { NIRODUCTION }}$}

Resuspension is the process by which wind blowing over a surface causes particles from that surface to be blown into the air and transported downwind. For radioactively contaminated surfaces, wind might cause radioactive particles to be suspended into the air and transported to other sites.

Resuspension is known to occur at radioactively contaminated sites on Washington's Hanford Reservation, (1) but with our present knowledge, amounts of wind-caused resuspension and its effects cannot be adequately predicted. Consequently the purposes of this study were:

1) to determine how much radionucl ide resuspension occurs, and

2) to use experimental results from local study sites to increase our knowledge of particle resuspension physics.

Airborne concentrations of ${ }^{239} \mathrm{Pu},{ }^{238} \mathrm{Pu},{ }^{137} \mathrm{Cs}$, and ${ }^{241} \mathrm{Am}$ were measured at several Hanford Reservation sites and compared with fallout levels measured at the 329 Building, 300 Area, approximately $30 \mathrm{~km}$ away. The objective of this comparison was to determine increases in concentrations of airborne radionuclides attributed to local resuspension from waste disposal sites on the Reservation.

Concentrations were measured as functions of wind speed, airborne particle size, wind direction, and the collected radionuclides determined per gram of airborne soil or solids. Particulate air samples were taken as a function of wind speed to determine whether airborne radionuclide concentrations increased at higher wind speeds, while concentrations as a function of particle size were measured to determine if radionuclides were resuspended as individual particles or attached to host soil and solid particles. In addition, airborne radionuclides were normalized by the total amount of airborne solids to relate concentration per gram of airborne solid to concentration per gram of radionuclides on the ground. This relationship between concentration per gram of airborne solid and concentration per gram of soil or solid on the ground can be used to estimate permissible ground surface contamination criteria for releasing areas for use by the general population. 


\section{$\underline{\text { CONCLUSIONS }}$}

Ranges of airborne concentrations of wind resuspended ${ }^{239} \mathrm{Pu},{ }^{241} \mathrm{Am}$, ${ }^{238} \mathrm{Pu},{ }^{137} \mathrm{Cs}$ and ${ }^{90} \mathrm{Sr}$ which occurred at study sites from 1972 to 1975 are summarized in this report. For limited data reported, airborne radionuclide concentrations increased with wind speed to the 1.0 to 1.5 Dower. Maximum airborne concentrations were: for ${ }^{239} \mathrm{Pu}, 8 \times 10^{-15}$ $\mathrm{\mu Ci} / \mathrm{cm}^{3}$; for ${ }^{241} \mathrm{Am}, 3 \times 10^{-15} \mathrm{\mu Ci} / \mathrm{cm}^{3}$; for ${ }^{238} \mathrm{Pu}, 8 \times 10^{-16} \mu \mathrm{Ci} / \mathrm{cm}^{3}$; and for ${ }^{137} \mathrm{Cs}, 3 \times 10^{-13} \mu \mathrm{Ci} / \mathrm{cm}^{3}$. These maximum airborne concentrations were less than corresponding 40-hr maximum permissible airborne concentrations $\left(\mathrm{MPC}_{40 \mathrm{hr}}\right.$ ) for these radionuclides. (a) Ratios of maximum airborne concentrations to $\mathrm{MPC}_{40 \mathrm{hr}}$ values were $4 \times 10^{-3}$ for ${ }^{239} \mathrm{Pu}, 5 \times 10^{-4}$ for ${ }^{241} \mathrm{Am}, 4 \times 10^{-4}$ for $238 \mathrm{Pu}$, and $5 \times 10^{-6}$ for ${ }^{137} \mathrm{Cs}$. Maximum concentrations per gram of airborne solid were: for ${ }^{239} \mathrm{Pu}, 6 \times 10^{-5} \mu \mathrm{Ci} / \mathrm{g}$; for ${ }^{241} \mathrm{Am}, 7 \times 10^{-5} \mu \mathrm{Ci} / \mathrm{g}$; for ${ }^{238} \mathrm{Pu}, 1 \times 10^{-6} \mu \mathrm{Ci} / \mathrm{g}$; and for ${ }^{137} \mathrm{Cs}, 1 \times 10^{-2}$ $\mu \mathrm{Ci} / \mathrm{g}$.

Resuspension factors were calculated from airborne concentrations measured in this study and literature values for surface contamination. Resuspension factors ranged from $4 \times 10^{-11}$ to $2 \times 10^{-5} \mathrm{~m}^{-1}$, and are within the range generally reported for other sites.

Radioactive particles may be resuspended either as individual particles or, more probably, attached to host soil or solid particles. In this study, most airborne radionuclide concentrations were reasonably uniform as a function of height and cross-wind distance. This uniformity

\footnotetext{
(a) The International Congress For Radiation Protection has established for different radionuclides the maximum permissible concentrations (MPCs) (2) allowable for continuous exposure during a 40-hr work week. MPCs were calculated to establish limits for permissible dose rates to critical organs. Models were used relating rate of uptake of a radionuclide into critical organs by inhalation (or ingestion) to the activity build-up in the organ and to biological and physical elimination from the organ.
} 
suggests an average or "normal"-activity radionuclide particle distribution is usually collected on sampling filters. However, one filter showed a plutonium concentration at least 30 times greater than the maximum for all other samples during this period. This anomalous higher concentration is attributed to one or more plutonium particles of unusually higher activity than those normally, or most frequently, resuspended.

The weathering half-life is the time required for airborne concentrations at a resuspension site to decrease by one-half. Weathering is probably a function of the source characteristics. However, very little is known about predicting weathering. For fallout, previous literature has indicated this half-life to be between 30 and 45 days. However, results of studies reported here indicate a resuspension half-life of 5 months or greater. Knowledge of this ill-defined half-1ife is important in modeling efforts to describe airborne effects of surface contamination. Changes in surface contamination availability with time must be known if models are to predict airborne concentrations. This range of 5 months or greater for a weathering half-life is an important new addition to resuspension literature.

Another important result of this research is the initial evidence that airborne concentrations of ${ }^{239} \mathrm{Pu},{ }^{247} \mathrm{Am},{ }^{238} \mathrm{Pu},{ }^{137} \mathrm{Cs}$, and ${ }^{90} \mathrm{Sr}$ increase as a function of wind speed to the 1.0 to 1.5 power. Previously, resuspension literature had not definitely shown that radionuclide concentrations increase with wind speed. In controlled source experiments, tracer particle resuspension rates increase with about the 5 th power of wind speed. (3) Differences between wind speed exponents of 1 and 5 need to be explained. Differences may be caused by the extent of the source area and downwind transport. 


\section{STUDY SITES}

The Hanford Reservation is an ideal site at which to measure resuspension and determine resuspension physics. Both nuclear reactors and separation plants have been operated here for over 30 years. Fuel elements have been processed and high- and low-level liquid wastes from those separation plant process streams have been stored and accumulated. $(4,5)$ These include low-level wastes discharged to ponds and trenches to be filtered through soil and sediments. As a result, residual radioactive materials in liquid waste are retained on soil particles or trench bottoms. Several areas of low-level waste disposal are the principal resuspension source sites discussed in this report.

Sites of low-1evel waste collection where resuspension was measured (Figure 1) include U-Pond area, S-16 area, and Z-19 ditch leading into U-Pond, all of which are within or near 200 West Area; the BC Crib area south of 200 East Area; the Gable Mountain Pond area; and an area close to the Hanford Meteorological Station Tower near 200 West Area. Waste disposal continues at U-Pond, Z-19 ditch, and Gable Mountain Pond. The

ileg. No. PNL 768423-7

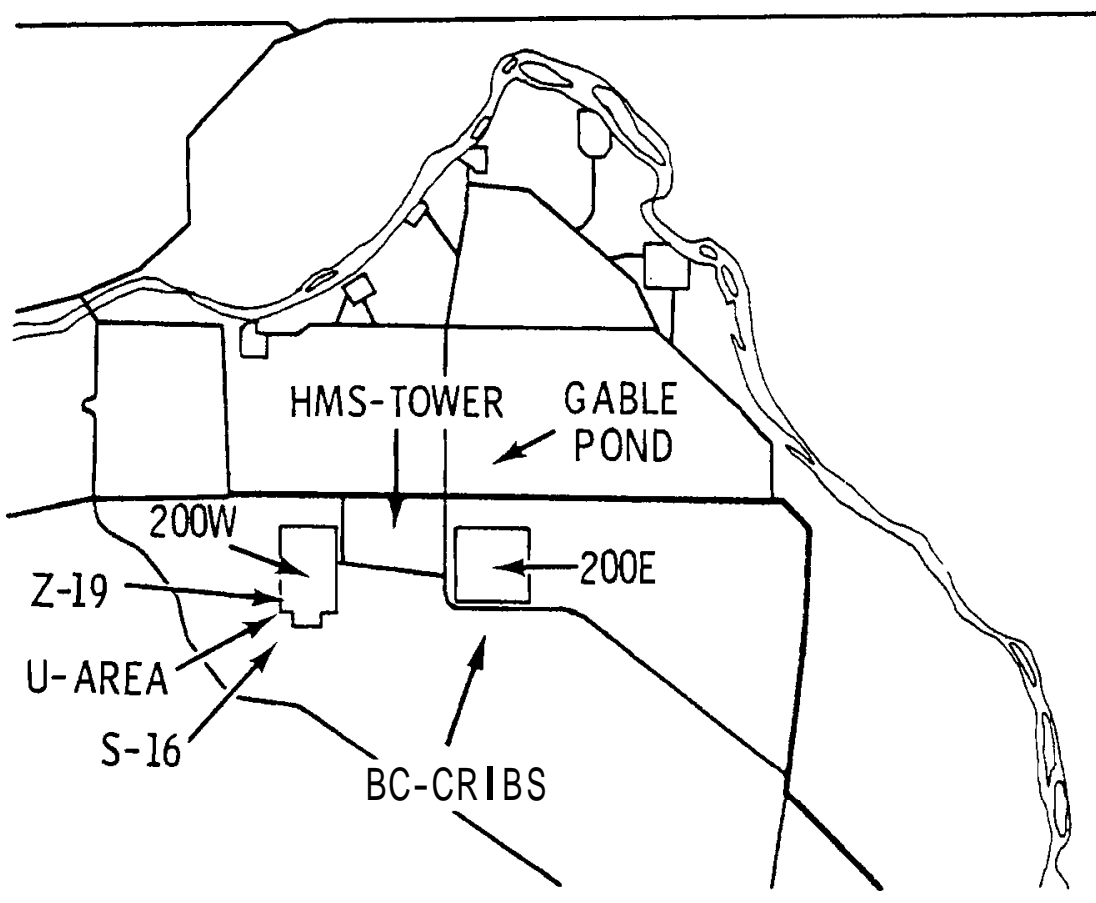

FIGURE 1. Location of Resuspension Sites 
S-16 area has been covered. All trenches in the BC-Crib area are covered but were exposed when initially used.

\section{U-POND AND BC-CRIB AREAS}

One principal resuspension study site was U-Pond. In 1944, a shallow depression was turned into a pond to receive low-level radioactive liquid waste from plutonium processing and reclamation facilities, a uranium recovery plant, several laboratories, and a laundry. Except for the laboratories, these waste sources still contribute to U-Pond, although the surface area of the pond has decreased from about $120,000 \mathrm{~m}^{2}$ (in 1952) to about $56,000 \mathrm{~m}^{2}$. (4)

The water level at U-Pond is maintained by three major sources: the plutonium processing operations (through Z-19 ditch); the laundry (through U-14 trench); and the evaporator-crystalijzer plant (also through U-14 trench). (4) Laundry waste and cooling water continuously flow through these trenches into the pond. Liquid effluents sometimes carry low-level waste $\left(<5 \times 10^{-b} \mu \mathrm{Ci} / \mathrm{cc}\right)$ containing plutonium, americium, and low-level fission products including ${ }^{137} \mathrm{Cs}$ to the pond. In addition, plutonium releases, which are usually at low levels, occur on an intermittent basis. Release records ${ }^{(5)}$ indicate the total plutonium discharge to the U-Pond area may be about $8.1 \mathrm{~kg}$, while measurements $(5, \mathrm{p} .41)$ taken in 1974 showed an estimated $21 \mathrm{~g}$ total plutonium in the first $10 \mathrm{~cm}$ of U-Pond sediments. $(6,7)$

The BC-Crib area, south of 200 East Area, was a second principal resuspension study site. From 1952 to 1958 liquid wastes containing aged fission products were removed from underground storage tanks. After uranium was recovered from these liquids, ${ }^{137} \mathrm{Cs}$ and ${ }^{90} \mathrm{Sr}$ concentrations were reduced by precipitate scavenging. The supernatant liquid was released into the $B C$ crib and trenches.

Soon thereafter, perhaps in 1959, an animal burrowed $(4,8,9,10)$ into the trenches and exposed a salt layer. In succeeding years rabbits apparently used this layer as a salt lick, as evidenced by the presence of "hot" radioactive fecal pellets as far away as $4 \mathrm{~km}$ from the original 
burrow site. When this was discovered, the hole was filled with gravel and sealed with asphalt. In 1969 the trenches were covered further with sand and gravel. The contaminated area, which extends beyond the immediate vicinity of the burrow, is designated as the BC-Crib Controlled Area. At present, surface radioactivity is associated mainly with rabbit fecal pellets and urine deposited on the ground. $(4,8,9,10)$

Contaminated zones in U-Pond and $\mathrm{BC}$-Crib areas were identified in 1973 by means of a helicopter survey. (8) In BC-Crib area, the radiation survey showed surface contamination to be $1-10 \mu \mathrm{Ci} / \mathrm{m}^{2}$ in an area of $2.3 \mathrm{~km}^{2}$. A larger $\left(8 \mathrm{~km}^{2}\right)$, less contaminated area showed a surface concentration of less than $1 \mu \mathrm{Ci} / \mathrm{m}^{2}$. Total radioactivity to a depth of 2.5 on was computed to be approximately $40 \mathrm{Ci}\left(32 \mathrm{Ci}\right.$ of ${ }^{90} \mathrm{Sr}$ and $8 \mathrm{Ci}$ of $\left.{ }^{137} \mathrm{Cs}\right)$. Surface samples indicated ${ }^{137} \mathrm{Cs}$ tends to remain nearer the soil surface than ${ }^{90} \mathrm{Sr}$, which separates and leaches downward.

Effects of past resuspension were revealed by the aerial survey. For instance, ${ }^{241}$ Am was measured around U-Pond area (which includes the discharge area for the Z-19 ditch). Ground contours indicate southwest winds blew through Z-19 ditch and deposited ${ }^{241}$ Am on banks northeast of the ditch bend. We subsequently measured air concentrations of resuspended radionuclides at this site. Aerial survey contours also showed ${ }^{137}$ Cs around contours around U-Pond area. These curves also indicated that southwest winds transported ${ }^{137} \mathrm{Cs}$ from the U-Pond area.

In contrast, ${ }^{137} \mathrm{Cs}$ ground contours in BC-Crib area were not as informative. There, areas of contamination were more isolated, because of the random deposition of rabbit pellets. Nevertheless, the region of highest concentration was near the original $B C$ trench areas, and $\mathbf{i t}$ was in this area that airborne concentrations were measured.

\section{OTHER RESUSPENSION STUDY SITES}

Resuspension studies were conducted on a shorter-term basis at S-16 area, Gable Mountain Pond, and near the Hanford Meteorological Station (HMS) Tower. The S-16 area was at one time covered with water but in 1975 was 
dry; resuspension was measured during this dry period. The ground surface in the vicinity of the meteorological tower is not a prime source of radionuclide resuspension, but high-velocity southwest winds can carry resuspended material from 200 West Area to this area.

\section{RESUSPENSION EXPERIMENTS}

The earliest and simplest experiments were done at Gable Mountain Pond and near the HMS Tower. Later, more extensive experiments with increasingly sophisticated instrumentation were conducted at remaining sites. In these experiments meteorological sensing instrumentation was used to operate air samplers automatically as functions of wind speed increments and wind direction. These experiments were designed to test for increased airborne radionuclide concentrations at higher wind speeds, to determine resuspension physics, and to gather data for estimating mass balances across contaminated zones. Upwind airborne radionuclide concentrations were simultaneously measured with downwind airborne concentrations for the purpose of determining whether resuspension caused increased airborne radionuclide levels between upwind and downwind airborne particle sampling towers. In initial experiments, samples were collected and total radioactivity determined. In later experiments, air filters were preweighed before use. After sample collection, filters were again weighed. With this technique it was possible to calculate the radionuclide concentration per gram of airborne solid collected.

\section{EXPERIMENTAL CONDITIONS}

Experimental conditions for each sampling site are summarized in Table 1. The two sampler types used were high-volume air samplers, which sampled at $1.13 \mathrm{~m} / \mathrm{min}$, and cascade particle impactors, which sampled at $0.57 \mathrm{~m}^{3} / \mathrm{min}$. High volume air samplers with $20 \times 25 \mathrm{~cm}$ ( $8 \times 10$ in.) filter holders were used at all locations, and were faced into the wind toward upwind towers. Particle cascade impactors, however, were used only in some experiments at U-Pond, BC-Crib, and in the HVS Tower experiment. 
TABLE 1. Summary of Experimental Parameters

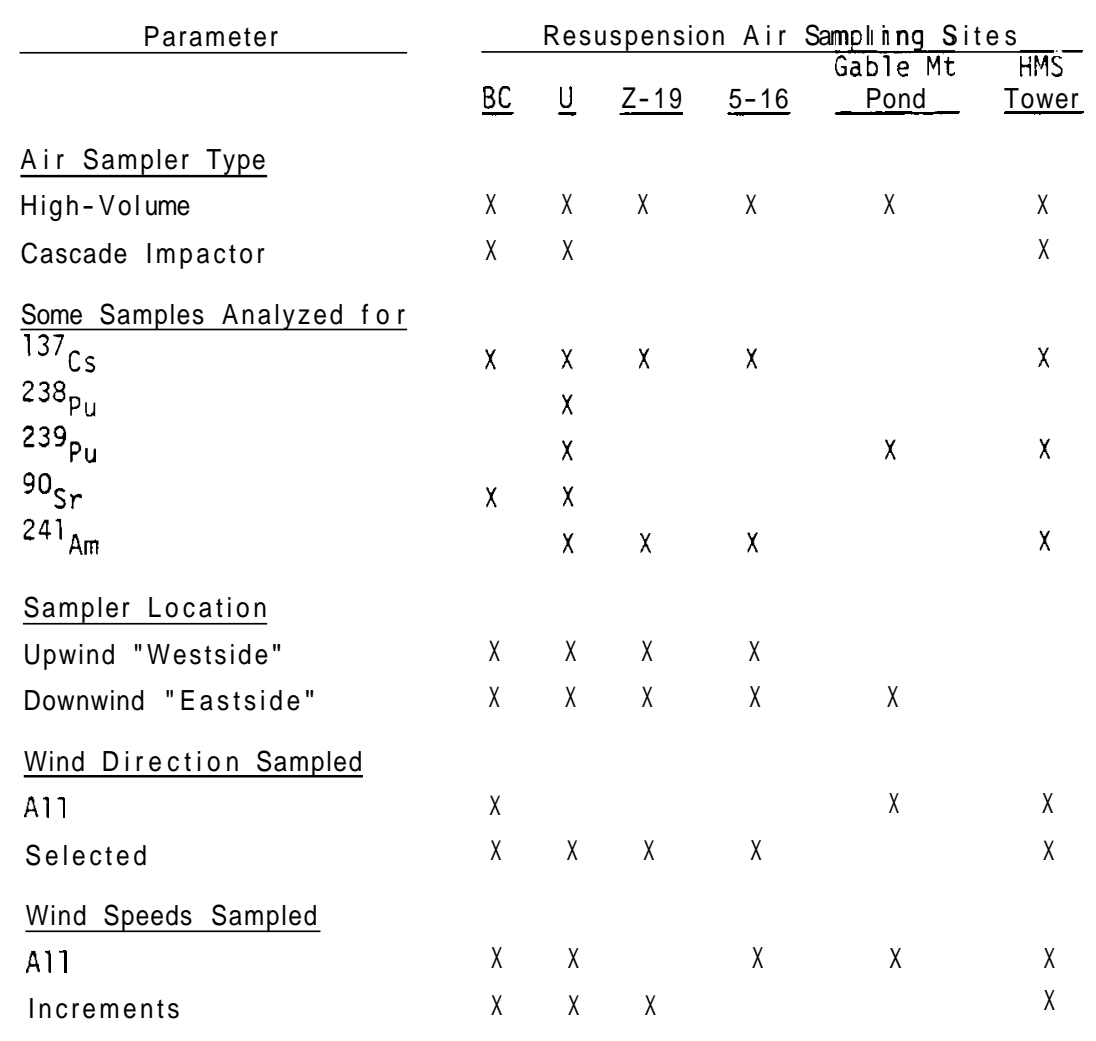

Cascade particle impactors separated airborne particles into respirablesize fractions. (a) Impactor 50\% stage cutoff diameters were 7, 3.3, 2, and $1.1 \mu \mathrm{m}$. In most cases a rotating cowl ${ }^{(11)}$ fitted with a tail fin to rotate the inlet into the wind was attached to the particle cascade impactor. Particles larger than respirable size were driven into the cowl and deposited on the cowl bottom. Particles of respirable size remained airborne and were drawn up into the cascade impactor which fitted into the cowl. Thus by using the cowl impactor system, airborne radionuclide concentrations were determined on nonrespirable as well as respirable particle sizes.

\footnotetext{
(a) "Respirable" as used in this report are those particles which are found on the impactor stages and back-up filter.
} 


\section{$\underline{\text { BC-Crib Area }}$}

One upwind tower and eleven downwind towers were used at BC-Crib area. A ir samplers were located at heights from 0.3 to $6 \mathrm{~m}$ above ground level. The distance between upwind and downwind tower arrays was approxi mately $770 \mathrm{~m}$. This region between towers included the area of highest ${ }^{137}$ Cs surface contamination. However, both tower arrays were within areas of lower surface contamination. Initially, samples were taken for all wind speeds and wind directions. In subsequent experiments, samples were taken as a function of three wind speed increments and only when wind was blowing from upwind to downwind towers.

\section{U-Pond Area}

There were eleven downwind towers and only one upwind tower since U-Pond was assumed to be the resuspension source. Spacing between upwind and downwind towers was approximately $480 \mathrm{~m}$. Samplers were located from 0.3 to $30 \mathrm{~m}$ above ground level and samples were collected as functions of wind speed increments and wind direction. Samples were only collected when wind blew from upwind to downwind tower arrays.

\section{Z-19 Ditch}

Air samplers were located along Z-19 ditch which empties into U-Pond (Figure 1). High winds from the southwest blow through the ditch and could resuspend material from the banks adjacent to fluctuating water levels. Since the aerial survey indicated ${ }^{241}$ Am ground contamination adjacent to the ditch, samplers were located near Z-19 ditch to determine if ${ }^{241}$ Am was still resuspending from this area. High-volume a ir samplers were located from 0.3 to $9 \mathrm{~m}$ above ground level. Selected air samplers were operated for four different wind speed increments when southwest winds blew through the ditch.

$\underline{\text { S-16 Area }}$

The S-16 area was a dry pond area that at one time had collected liquid wastes. In the spring of 1975, this area was covered to eliminate 
resuspension from the dry pond bottoms. Resuspension was measured immediately before covering. Downwind air samplers were located $0.6 \mathrm{~m}$ above ground level along the northern and eastern edges of S-16. An upwind air sampler was located approximately $600 \mathrm{~m}$ southwest of the downwind air samplers. This upwind sampler was the only air sampler at any resuspension study site (except for HMS Tower) located outside a general waste processing area. Samplers were activated only when wind blew from upwind toward downwind samplers. However, all wind speeds were sampled.

$\underline{\text { Gable Mountain Pond }}$

At Gable Mountain Pond, air samplers were located $0.3 \mathrm{~m}$ above ground level along the east side. These air samplers were manually operated for all wind speeds and directions. During the sampling period, wind blew principally from the west. These samples were analyzed for plutonium.

\section{Hanford Meteorological Station Tower}

Air samplers near the $\mathbf{M S}$ Tower were located $0.3 \mathrm{~m}$ above ground level. Three types of samplers were used: a cascade particle impactor, an inertial impaction collector, and a series of funnels ${ }^{(12)}$ stacked one within the other. The cascade particle impactor was used during the January 11, 1972, dust storm, but became overloaded. Another small, selforienting sampler adjacent to the cascade particle impactor also collected particles during this storm. This inertial impaction collector was a bottomless polyethylene bottle mounted horizontally on a rotating bearing. A tail fin was attached to the bottle in order to orient the open bottom of the collector into the wind. Samples from the cascade impactor, polyethylene bottle collector, and funnel sampler were analyzed for plutonium.

\section{SAMPER LOCATIONS}

Upwind and downwind towers were used at BC-Crib, U-Pond, 1-19, and S-16 areas. In early experiments, samplers on upwind and downwind towers were not always operated simultaneously, but simultaneous sampler 
operation was maintained in some later experiments by means of an electrical signal cable installed between upwind and downwind towers. The downwind (or east-side) towers at Gable Mountain Pond were the only set of towers used on that location.

SAMPLING WITH RESPECT TO WIND DIRECTION

Air blowing from all directions was sampled for some experiments at BC-Crib area, HMS Tower, and Gable Mountain Pond. In other experiments, a ir was sampled only when wind was blowing from a selected compass angle. The objective was to sample only air blowing from upwind to downwind air samplers.

SAMPLING AS A FUNCTION OF WIND SPEED

Sampling as a function of wind speed was carried out to help determine particle resuspension physics and to measure changes in air concentrations as a function of wind speed. In Table 1, the subheading "increments" means that only selected wind speeds were sampled. Thus, if wind speed were from 3 to $5 \mathrm{~m} / \mathrm{sec}$, one set of air samplers would be activated. If wind were from 5 to $7 \mathrm{~m} / \mathrm{sec}$, another series of air samplers would be activated. Up to six wind speed increments were used. The subheading "all" means air filter samples were collected during all wind conditions.

\section{RADIOCHEMICAL ANALYSES}

Air samples were analyzed by either ARHCO, PNL or LFE Environmental Laboratories of Richmond, California. $(13,14,15)$ Most samples were analyzed for ${ }^{137} \mathrm{Cs}$ by $\mathrm{ARHCO}(13)$ using gamma detector systems which used Compton and background suppression. The primary detector was a lithiumdrifted germanium $[\mathrm{Ge}(L \mathrm{~L})]$ crystal.

Some ${ }^{137}$ Cs results were obtained at PNL by counting with an 18an (7-in.) NaI well crystal. Some samples were analyzed for ${ }^{241} \mathrm{Am}$ and plutonium. Other analyses done at PNL were for ${ }^{241} \mathrm{Am}$ and plutonium. $(14,15)$ However, most plutonium analyses were done by LFE Laboratories. 
SITE FOR FALLOUT LEVEL COMPARISON

Radionuclide air concentrations at resuspension sites were compared to fallout levels measured at the 329 Building, 300 Area. $(16,17)$ This is a principal reference site (started in 1961) in the United States for measurements of airborne fallout radionuclides; other reference sites include Pt. Barrow, Alaska (10 years' data) and Quillayute, Washington (1-1/2 years' data).

\section{$\underline{\text { RESULTS }}$}

Extensive data were obtained on airborne radionuclide concentrations around resuspension sites studied. These concentrations are expressed both in $\mu \mathrm{Ci} / \mathrm{cm}^{3}$ of filtered air and $\mu \mathrm{Ci} / \mathrm{g}$ of airborne solids. This report summarizes ranges of data collected, but does not detail data for each experiment. Results can be summarized as follows:

- Airborne radionuclide concentrations increased as wind speeds increased.

- Measureable air concentrations extended up to $30 \mathrm{~m}$ above ground level which was the highest sampling elevation.

- Airborne concentrations at resuspension study sites were greater than those measured at the 300 Area (fallout levels) during the same time intervals. The only exception was for ${ }^{241}$ Am concentrations during March to May 1974, during which the ${ }^{241}$ Am was somewhat less than reported fallout levels.

In the following sections concentrations of ${ }^{137} \mathrm{Cs},{ }^{238} \mathrm{Pu},{ }^{239} \mathrm{Pu}$,
and ${ }^{241} \mathrm{Am}$ will be given and the effects of wind speed and sampling height will be described. Results wi11 be discussed in terms of maximum expected airborne concentrations, the ratio of concentrations on airborne 
solids and surficial solids, the average release flux of radionuclides from an assumed resuspension site, and the calculation of resuspension factors.

\section{EFFECT OF WND SPEED}

Airborne concentrations measured at several sites as a function of wind speed indicated airborne concentrations increased as wind speed increased. The data set selected for discussion is shown in Figure 2. These data were obtained at the sampling tower west of U-Pond from March 21 through My 20, 1974. Samples were collected when wind was blowing from $170^{\circ}$ to $340^{\circ}$ (north corresponds to $0^{\circ}$ and west to $270^{\circ}$ ). In this wind sector air was expected to be moving only from upwind uncontaminated surface areas except for the overflow area of U-Pond, which could be a resuspension source. High-volume air samplers were located $0.9 \mathrm{~m}$ and $3.0 \mathrm{~m}$ above ground level. Airborne radionuclide concentrations were measured for three wind speed increments of 1.3 to $3.6 \mathrm{~m} / \mathrm{sec}$, 3.6 to $5.8 \mathrm{~m} / \mathrm{sec}$, and 5.8 to $9.4 \mathrm{~m} / \mathrm{sec}$.

Fallout levels in 300 Area and U-Pond airborne concentrations $\left(\mu \mathrm{Ci} / \mathrm{cm}^{3}\right)$ for ${ }^{137} \mathrm{Cs},{ }^{90} \mathrm{Sr},{ }^{239} \mathrm{Pu}$, and ${ }^{241} \mathrm{Am}$ are shown in Figure 2. Concentrations are plotted at the lower limits of their respective wind speed increments. Data points for each height are plotted at each wind speed. Error bars shown are the maximum and minimum $2 \sigma$ counting statistics error limits for the two data points. Where error bars are not shown, the $2 \sigma$ limits do not extend beyond the data symbol.

Straight lines through data points indicate an exponential concentration increase with an increase in wind speed. The velocity exponent for ${ }^{137}$ Cs indicates that ${ }^{137}$ Cs concentrations increased with the 1.2 power of wind speed. In contrast, ${ }^{90} \mathrm{Sr}$ concentrations increased with the 1.0 power of wind speed. Both ${ }^{239} \mathrm{Pu}$ and ${ }^{241} \mathrm{Am}$ concentrations increased with the 1.5 power of wind speed. 


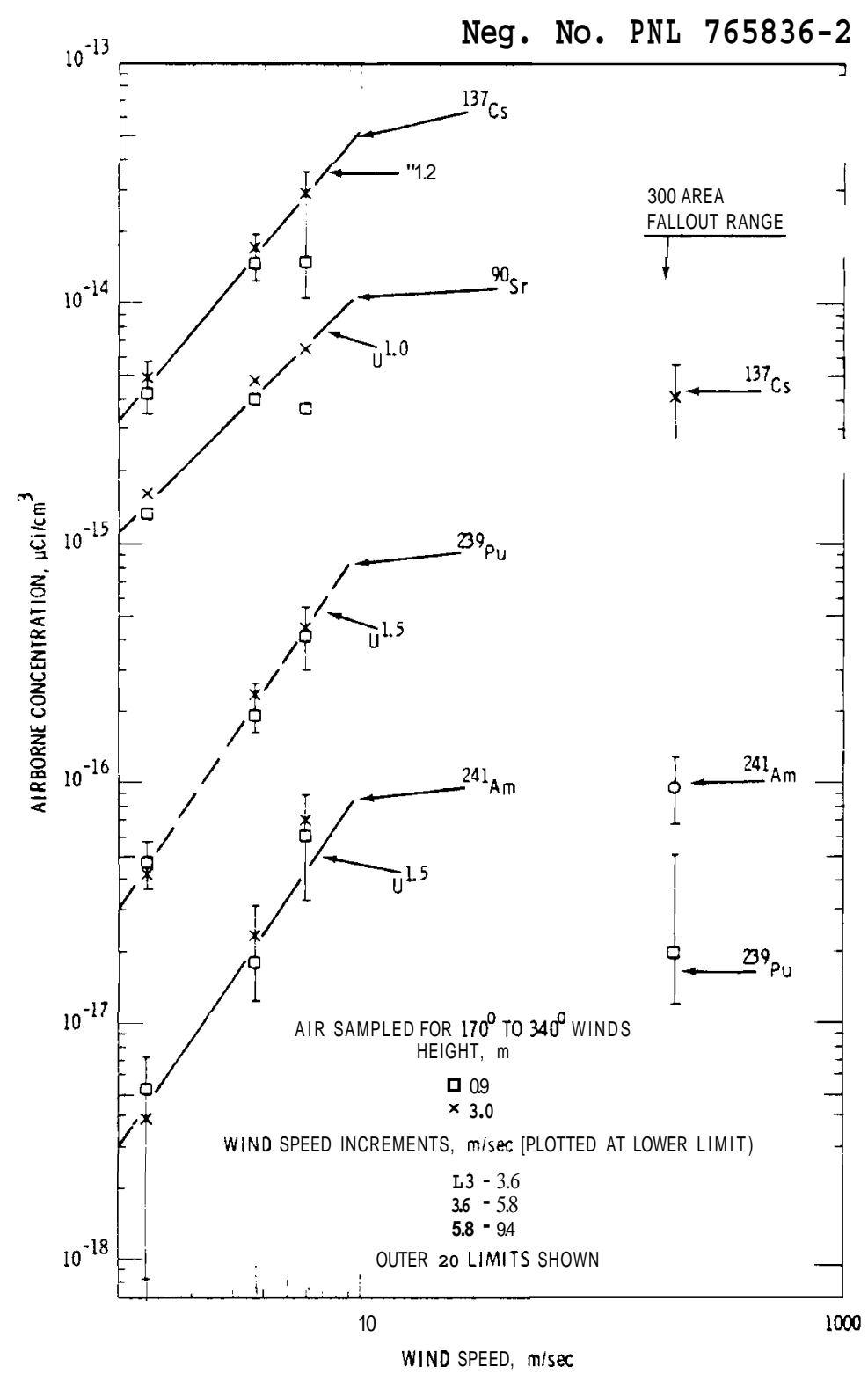

FIGURE 2. Airborne Radionuclide Concentrations as a Function of Wind Speed Nest of U-Pond (March 21 - May 20, 1974) in Relation to Fallout Levels in 300 Area 
Fallout levels in the 300 Area are shown on the right side of Figure 2. Cesium-137 and ${ }^{239} \mathrm{Pu}$ fallout concentrations were similar to concentrations measured during the lowest wind speed increment. In contrast, ${ }^{241}$ Am fallout concentrations were comparable to concentrations measured at the highest wind speed increment; the reasons for this variation are unknown. Strontium-90 fallout concentrations have not yet been reported for this time period. $(16,17)$

\section{AIRBORNE RADIORUCLIDE CONCENTRATION AS A FUNCTION OF HEIGHT}

Data collected from March 21 to May 20 were also used to determine airborne concentrations as a function of height. Concentration data east of U-Pond (shown in Figure 3) were obtained for all winds from 1.3 to $9.4 \mathrm{~m} / \mathrm{sec}$ when the wind direction was from $170^{\circ}$ to $340^{\circ}$. Airborne concentrations are shown as a function of height for ${ }^{238} \mathrm{Pu},{ }^{241} \mathrm{Am}$, ${ }^{239} \mathrm{Pu},{ }^{90} \mathrm{Sr}$, and ${ }^{137} \mathrm{Cs}$. Error bars shown around data points are $2 \sigma$ counting statistics limits; error bars are shown only if limits are wider than data symbols. These profiles show that concentrations were nearly uniform for the range of heights studied.

These concentrations are normally greater than 300 Area fallout level ranges shown in the lower portion of Figure 3. Concentrations of ${ }^{238} \mathrm{Pu}$ are all definitely greater than fallout levels, while ${ }^{137} \mathrm{Cs}$ concentrations are only slightly greater than fallout levels. Even though resuspension occurred, measured air concentrations were al1 below their respective MPC values even for uncontrolled areas. The only ambiguity in this data set is the ${ }^{241}$ Am results. Fallout levels for ${ }^{241}$ Am in the 300 Area were greater than concentrations measured at U-Pond. 
Neg. No. PNL 765724-2

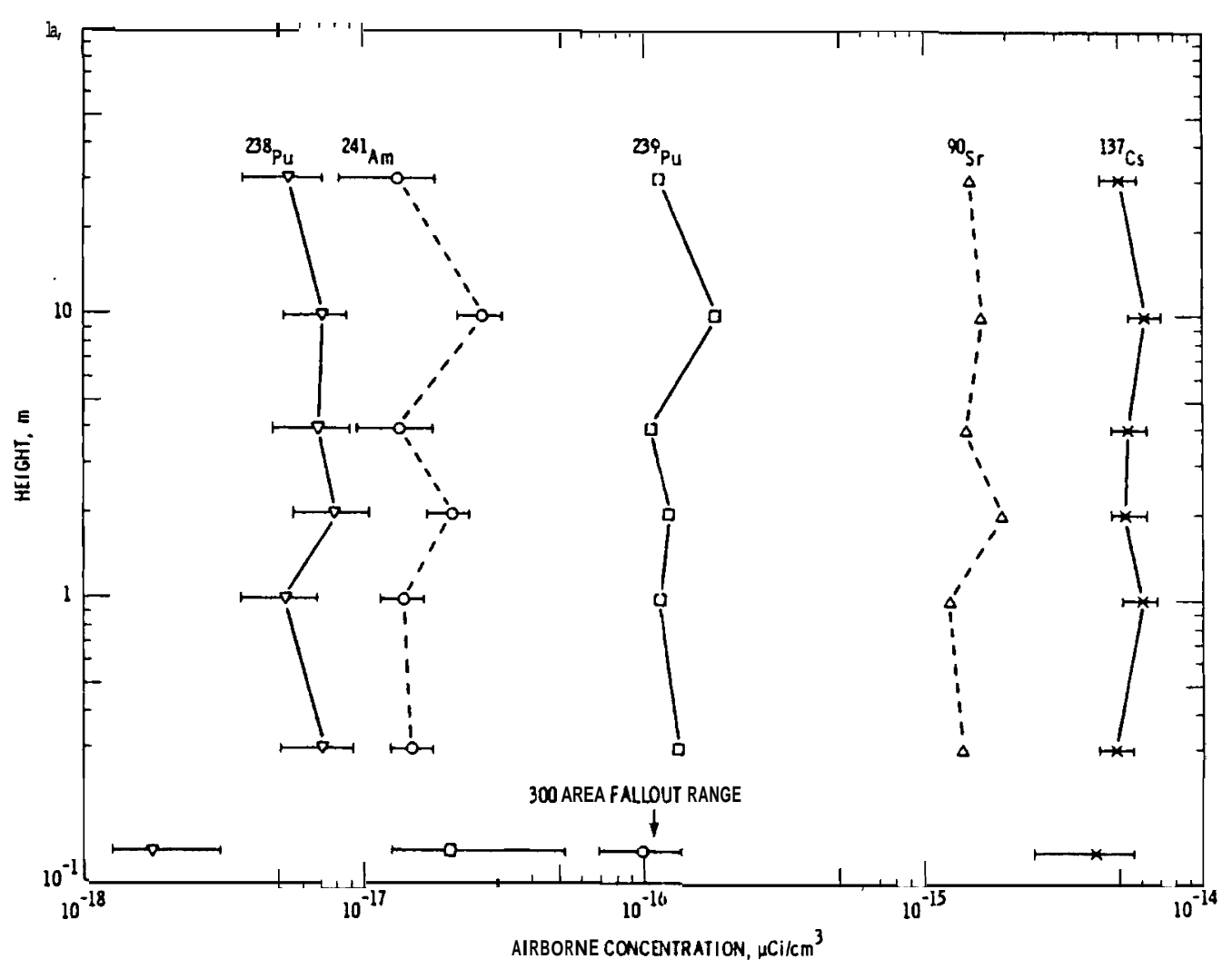

FGURE 3. Airborne Radionuclide Concentrations as a Function of Height East of U-Pond (March 21 - May 20, 1974)

\section{CESIUM-137 CONCENIRATIONS}

Ranges of airborne ${ }^{137}$ Cs concentrations at U-Pond, BC Crib, Z-19, S-16, and HMS Tower areas determined in these resuspension experiments are summarized in Figure 4. The data represent experiments conducted over various time periods. For each data symbol, the vertical line is plotted at the mid-time of the experiment while the experiment duration is shown by horizontal lines drawn at both the maximum and minimum measured concentration.

Airborne ${ }^{137}$ Cs concentrations are shown as a function of time from 1973 to 1975. In comparison, 300 Area fallout levels are shown by horizontal dashed lines. Measured airborne concentrations at each resuspension site are above fallout levels. The maximum airborne ${ }^{137}$ Cs concentration was 
$3 \times 10^{-13} \mathrm{LCi} / \mathrm{cm}^{3}$, which is more than two orders of magnitude greater than fallout levels but significantly less than the $M_{40} C_{4 r}$ of $6 \times 10^{-8}$ $\mathrm{LC} / \mathrm{cm}^{3}$.

Neg. No. PNL 765724-7

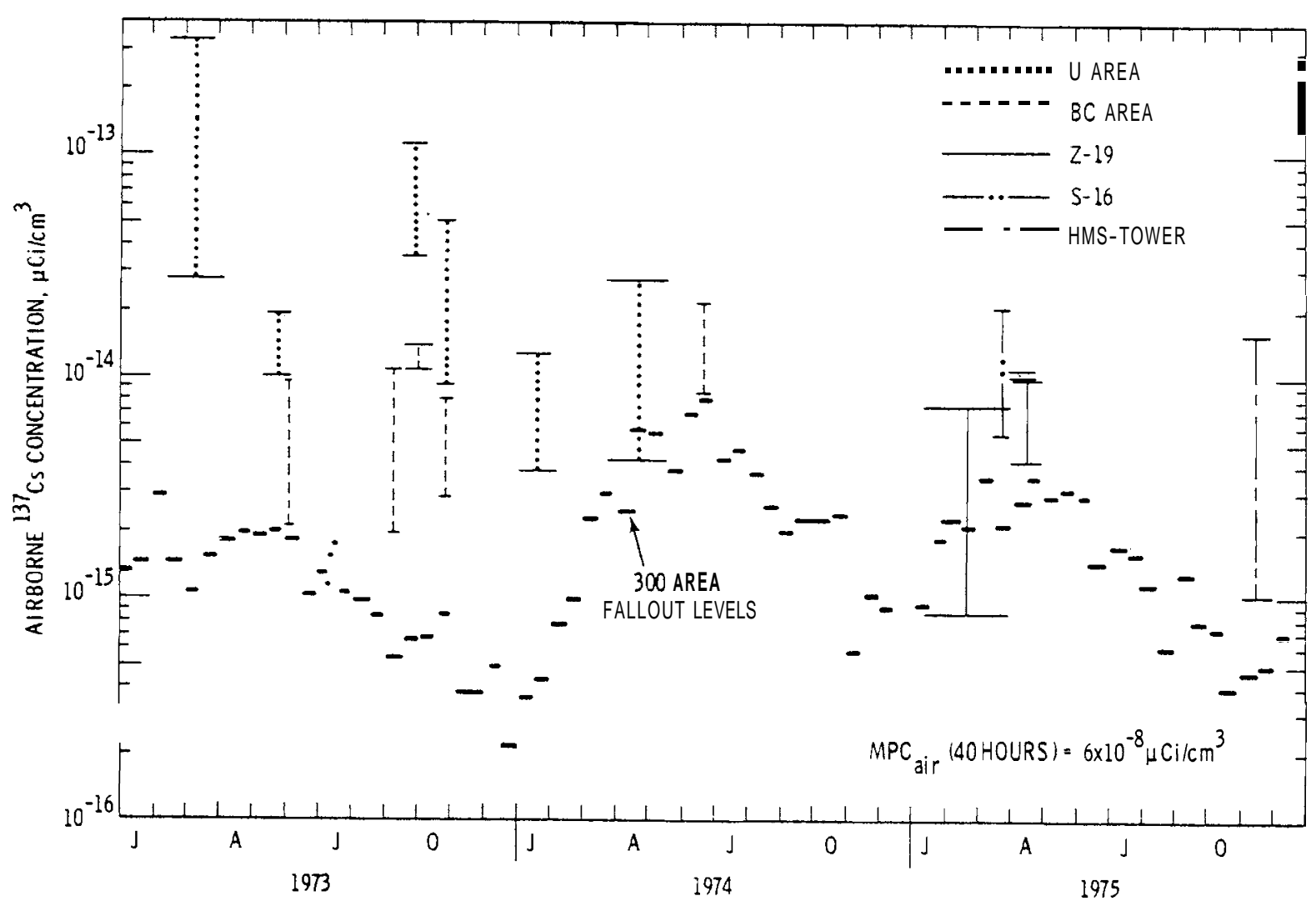

FIGURE 4. Range of Downwind Airborne ${ }^{137}$ CS Concentrations at Resuspension Sites Compared to Fallout Levels

Airborne concentrations at U-Pond tended to decrease from 1973 through mid-1974. On the average, air concentrations decreased by onehalf over a 5-month period. This decrease indicates that the weathering (or fixation) half-life for surface contamination available for resuspension is approxiniately 5 months. This is much greater than the 35 to 40 days often quoted ${ }^{(18)}$ in resuspension 7iterature. However, the 5-month weathering half-life at U-Pond could be a manifestation of some resuspension surface 
renewal process since this is an active waste site. The explanations are unclear for differences in weathering half-life. Nevertheless, caution is indicated in trying to extrapolate backwards in time prior to the research. The data reported herein concern only the time period for which resuspension research was conducted.

In contrast, BC-Crib air concentration data do not show any such short fixation half-life. Airborne concentrations at BC-Crib tended to remain constant from My 1973 to June 1974, suggesting a fixation half-life of years. If the concept of a fixation half-life is valid, differences in half-life appear to be from five months or greater for this data set.

Airborne ${ }^{137}$ Cs concentrations are normalized by the solids collected on each filter. Airborne concentrations shown in Figure 5 ranged from $10^{-5}$ to $10^{-2} \mu \mathrm{Ci} / \mathrm{g}$ of airborne solid. The largest concentrations were measured around U-Pond in September - October 1973. The airborne concentration per gram is reasonably uniform for the different resuspension sites.

Neg. No. PNL 765724-7

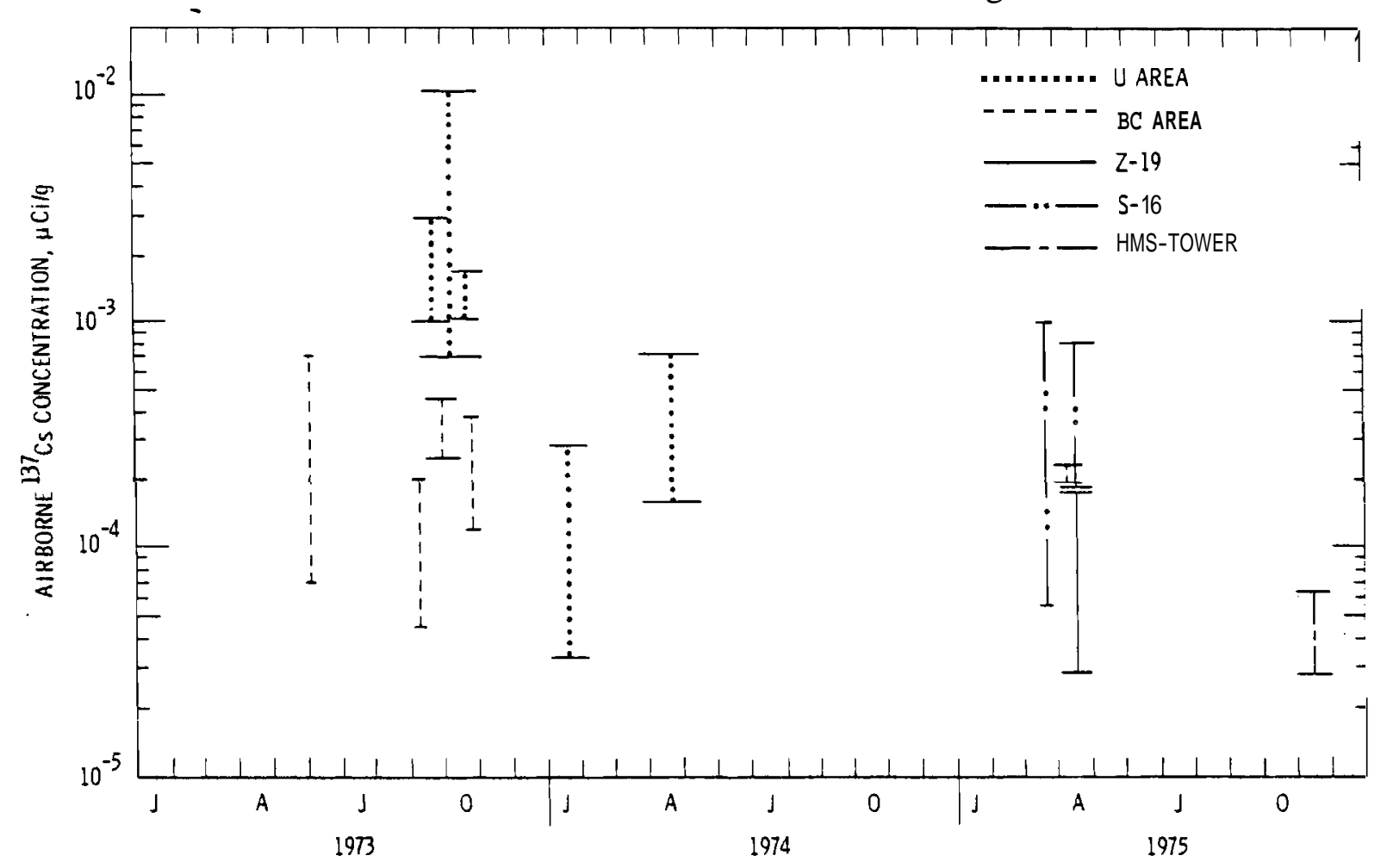

FIGURE 5. Range of Downwind ${ }^{137}$ CS Concentrations on Airborne Solids at Resuspension Sites 


\section{PLUTONIUM CONCENTRATIONS}

Airborne plutonium concentrations for both ${ }^{238} \mathrm{Pu}$ and ${ }^{239} \mathrm{Pu}$ measured in these resuspension experiments are shown in Figure 6 and are compared with 300 Area fallout levels. Airborne peak plutonium concentrations at resuspension study sites were significantly greater than 300 Area fallout levels, and airborne ${ }^{239}$ Pu concentrations in general were greater than airborne ${ }^{238}$ Pu concentrations. However, although resuspension was and is still probably occurring at these sites, measured airborne concentrations were significantly less than MPC's.

Neg. No. PNL 765724-4

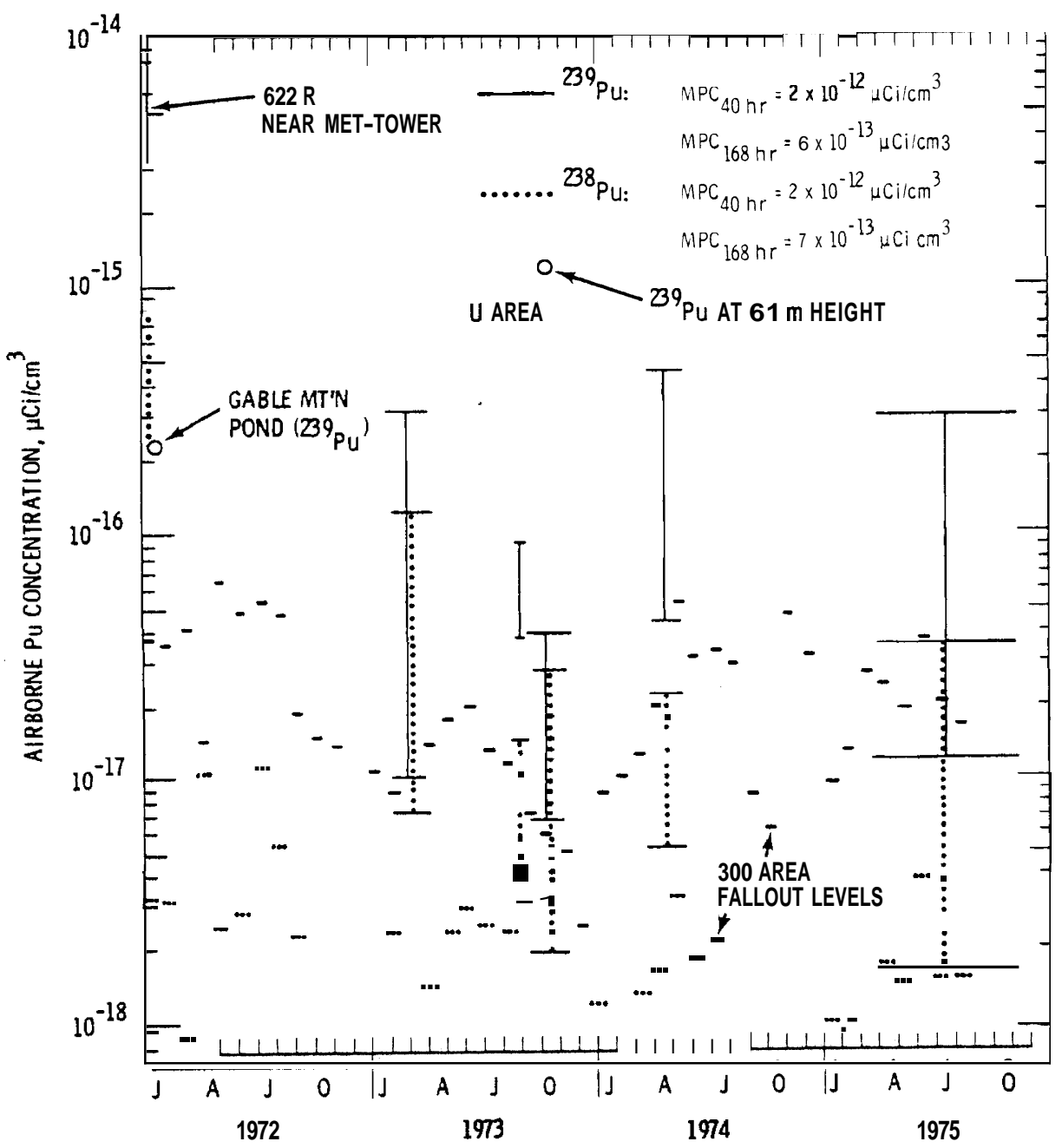

FIGURE 6. Range of Airborne Plutonium Concentrations at Resuspension Sites Compared to Fallout Levels 
The maximum airborne ${ }^{239} \mathrm{Pu}$ concentration measured was $8 \times 10^{-15} \mu \mathrm{Ci} / \mathrm{cm} 3$ near the HMS Tower on January 11, 1972. All other plutonium concentrations except one were at least one order of magnitude lower. The one exception was measured $6.1 \mathrm{~m}$ above ground at U-Pond during October 1973. In comparison with other October data, the concentration for this sample was about one and one half orders of magnitude greater than any other sample. Wypothesized that some more active-than-normal particles or clusters of particles were resuspended and collected on this filter.

After 1972, the only plutonium analyses were for some U-Pond samples. These airborne concentrations tended to be independent of sampling time, indicating the half life of plutonium available for resuspension was very long for this data set.

Airborne ${ }^{238} \mathrm{Pu}$ and ${ }^{239} \mathrm{Pu}$ concentrations expressed in $\mu \mathrm{Ci} / \mathrm{g}$ of airborne solids are shown in Figure 7. Concentrations of ${ }^{239} \mathrm{Pu}$ were somewhat greater than those of ${ }^{238} \mathrm{Pu}$. Plutonium concentrations on airborne solids ranged from $10^{-9}$ to $10^{-5} \mu \mathrm{Ci} / \mathrm{g}$. The only exception was the October 1973 single sample described above, for which the concentration was $6 \times 10^{-5} \mu \mathrm{Ci} / \mathrm{g}$. Otherwise, plutonium concentrations on airborne solids around U-pond appeared to be nearly independent of time.

\section{AMERICIUM-241 CONCENIRATIONS}

Airborne ${ }^{241}$ Am concentrations measured at U-Pond, Z-19, 5-16 and HS Tower areas ranged from about $10^{-18}$ to $10^{-15} \mu \mathrm{Ci} / \mathrm{cm}^{3}$. However, other filter samples indicated total ${ }^{241}$ Am collected was below radiochemical detection limits. In this figure airborne ${ }^{241}$ Am concentrations are compared to 300 Area fallout levels. However, the comparisons are incomplete since ${ }^{241} \mathrm{Am}$ fallout level data were not reported for all time periods. In addition, many fallout level data were below radiochemical detection limits; these are indicated by short horizontal dotted lines. Obviously, actual fallout levels for these time periods could have been significantly less. 


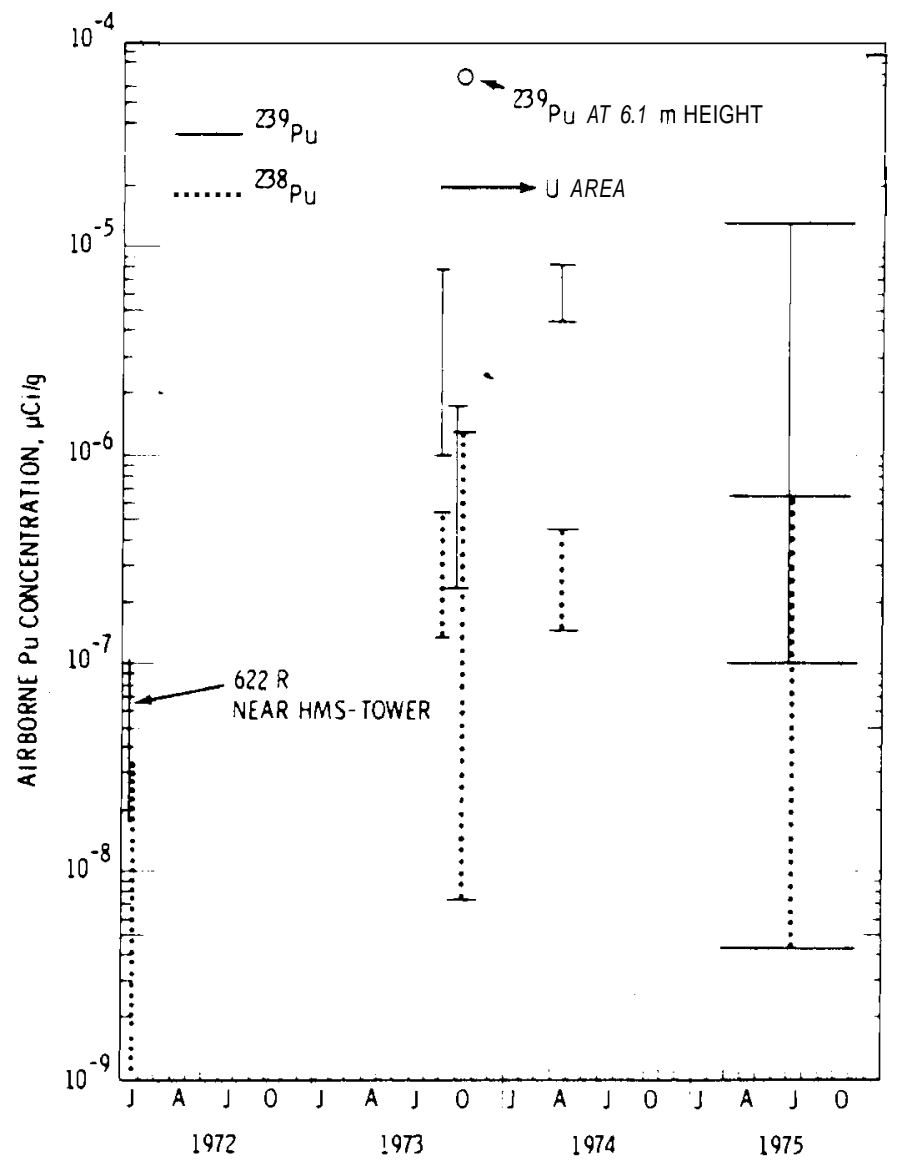

Neg. No. PNL 765724-9

.

FIGURE 7. Range of Pu concentration on Airborne Solids at Resuspension Sites

Neg. No. PNL 765724-11

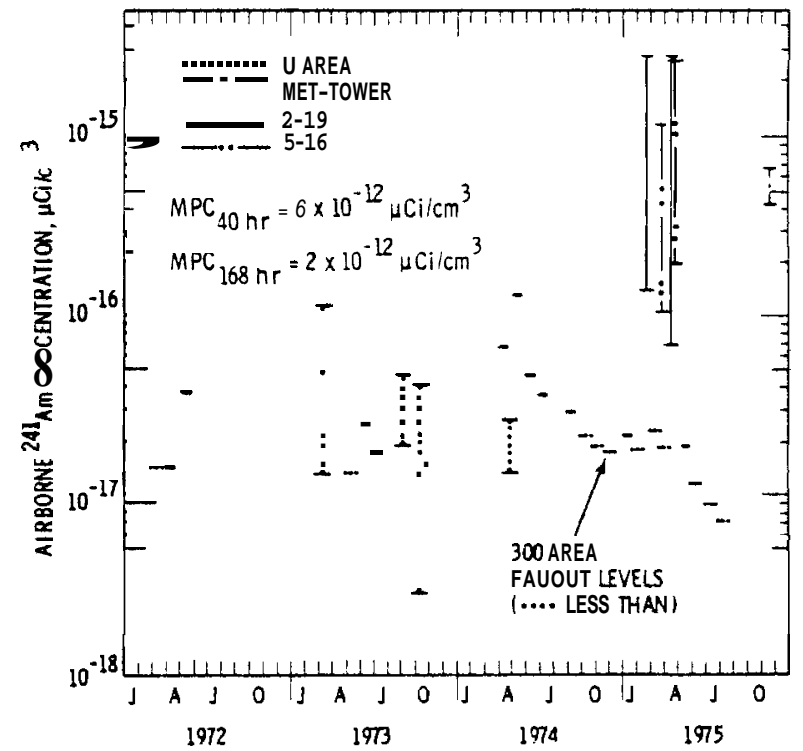

FIGURE 8. Range of Airborne ${ }^{241}$ Am Concentrations (Above Radiochemical Detection Limits) at Resuspension Sites Compared to Fallout Levels 
Airborne ${ }^{241} \mathrm{Am}$ concentrations at U-Pond were of the same order of magnitude as fallout levels. In contrast, airborne concentrations at Z-19 and S-16 were significantly above fallout levels during February to May 1975. Comparisons of upwind and downwind tower air sample results at S-16 showed increased ${ }^{241} \mathrm{Am}$ airborne concentrations were from ${ }^{241} \mathrm{Am}$ resuspension from the dry S-16 area. (This area has since been covered.) Maximum ${ }^{241}$ Am concentrations measured in November 1975 at the HM Tower are also comparable to concentrations measured at S-16 and Z-19. However, ${ }^{241} \mathrm{Am}$ was above radiochemical detection limits on only two HS Tower air filters for this time period.

Concentrations of ${ }^{241} \mathrm{Am}$ on airborne solids at each resuspension site, shown in Figure 9, ranged from about $10^{-7}$ to $10^{-4} \mu \mathrm{Ci} / \mathrm{g}$ of airborne solids. Airborne concentrations were least for U-Pond and greatest for Z-19 and S-16 areas. For the HMS Tower data, the arrow shown below the limits of the two positive ${ }^{241} \mathrm{Am}$ results indicates that many air filters had collected less than radiochemical detection 1imits. Nevertheless, maximum ${ }^{241} \mathrm{Am}$ concentrations per gram of airborne solids at the HS Tower for these two samples were comparable to concentration ranges measured at Z-19 and S-16.

Neg. No. PNL 765724-5

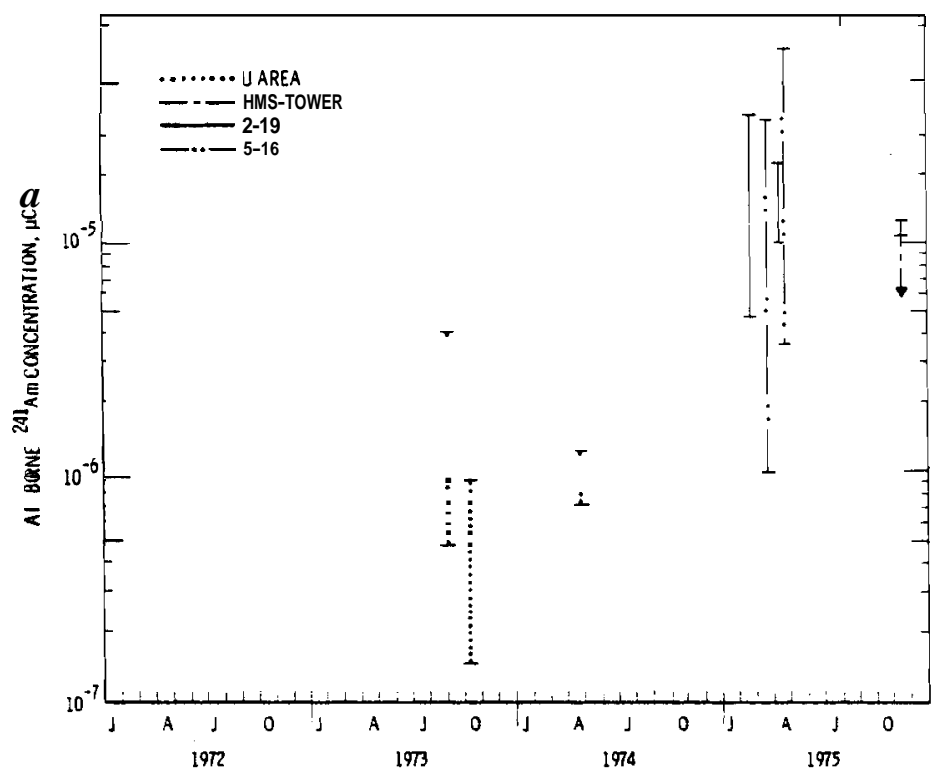

FGURE 9. Range of ${ }^{241}$ Am Concentrations on Airborne Solids at Resuspension Sites 


\section{DISCUSSION OF RESULTS}

Ranges of airborne radionuclide concentrations were outlined in the preceding section. Measurements at resuspension sites led to the following conclusions:

- Usually the amount of resuspended plutonium attached to most solid particles corresponds to a "normal" or average radioactivity size range; however, occasionally plutonium is resuspended as particles or clusters of particles of greater than this average actitivy.

Airborne concentrations of ${ }^{137} \mathrm{Cs},{ }^{239} \mathrm{Pu},{ }^{238} \mathrm{Pu}$, and ${ }^{241} \mathrm{Am}$ at the different resuspension sites were generally greater than fallout levels in the 300 Area.

Airborne concentrations increased with wind speed to the 1.0 to 1.5 power for the data shown.

- Airborne concentrations decreased with concentration half-lives of 5 months or greater.

In this section, results are discussed in greater detail. Additional data interpretations will include a prediction of airborne radionuclide concentrations from airborne soil concentrations. These interpretations are based on calculations and comparisons of airborne radionuclide concentrations (in amount per unit air volume and amount per mass of airborne solids) as well as the surface contamination per unit area of ground surface and per mass of solids on the ground. Resuspension factors are calculated and maximum airborne concentrations estimated.

\section{RELATIVE AMOUNTS OF RADIONUCUDES ON PARTICLES RESUSPENDED}

Data from this study indicated that apparently both normal and some more radioactive-than-normal particles or clusters of radioactive particles were resuspended and collected on sampl ing filters. In the October 1973 plutonium data shown in Figures 6 and 7, one filter at 6.1-m height collected $6.5 \times 10^{-5} \mathrm{\mu i} / \mathrm{g}$ airborne solid $\left(1.2 \times 10^{-15} \mathrm{\mu Ci} / \mathrm{cm}^{3}\right.$ of filtered air). This plutonium measurement was 36 times greater than the maximum 
value of $1.8 \times 10^{-6} \mu \mathrm{Ci} / \mathrm{g}$ airborne solid $\left(4.0 \times 10^{-17} \mu \mathrm{Ci} / \mathrm{cm}^{3}\right.$ of filtered air) collected on other filters simultaneously sampling at heights of 6.1 and $0.3 \mathrm{~m}$. We hypothesize that this relatively high plutonium collection on this filter was due to collection of one or more larger (more radioactive than normal) particles or clusters of particles.

The size of the larger particle(s) cannot be measured since the filter samples were dissolved for plutonium analysis. Nevertheless, the relative size can be estimated from the ratio of radioactivities collected for "normal" and "larger" particle sizes. Assuming that a particle's radioactivity is proportional to its volume, then the filter with a plutonium activity 36(30) times greater the next highest measured activity may have collected "larger" particles of 36(30) times the volume of "normal" particles. This would correspond to a diameter for the larger, less frequently resuspended particle(s) which may be three times the diameter of normally resuspended plutonium particles. Only since extensive air samples have been collected is the occurrence of these larger resuspended particles being experimentally recognized. However, the frequency of their resuspension appears to be very low.

The presence of a more radioactive than normal resuspended particle is also indicated by the ${ }^{241}$ Am data shown in Figures 8 and 9 . The two positive 241 Am air samples for the HS Tower may indicate that larger than normal ${ }^{241}$ Am particles or clusters of particles were collected on these filters.

A similar result was reported ${ }^{(19)}$ for resuspended particles at Rocky Flats, Colorado. In that experiment, a more radioactive than average particle (or cluster of particles) was collected on the 2- $\mu m$ stage of a particle cascade impactor.

\section{AIR CONCENIRATIONS N REATION TO MPCS}

Airborne concentrations ranges in $\mu \mathrm{Ci} / \mathrm{cm}^{3}$ were shown in Figures 4, 6, and 8. The maximum of each range was related to the MPC values for the occupational worker (40-hour work week) in Table 2. Maximum airborne concentrations were from $4 \times 10^{-3}$ to $5 \times 10^{-6}$ of $\mathrm{MPC}_{40} \mathrm{hr}$. These small ratios indicate an insignificant airborne inhalation hazard. 
TABLE 2. Ratio of Maximum Measured Airborne Concentrations to MPC air

A ir Concentration,

\begin{tabular}{|c|c|c|c|}
\hline Material & $\begin{array}{l}\text { Maximum } \\
\text { Observed }\end{array}$ & $\mathrm{MPC}_{40}(\mathbf{h r})$ & $\begin{array}{c}\text { Ratio, } \\
\text { Maximum/MPC } \\
\end{array}$ \\
\hline${ }^{239} \mathrm{pu}$ & $8 \times 10^{-15}$ & $2 \times 10^{-12}$ & $4 \times 10^{-3}$ \\
\hline${ }^{241} \mathrm{Am}$ & $3 \times 10^{-15}$ & $6 \times 10^{-12}$ & $5 \times 10^{-4}$ \\
\hline${ }^{238} \mathrm{Pu}$ & $8 \times 10^{-16}$ & $2 \times 10^{-12}$ & $4 \times 10^{-4}$ \\
\hline${ }^{137} \mathrm{Cs}$ & $3 \times 10^{-13}$ & $6 \times 10^{-8}$ & $5 \times 10^{-6}$ \\
\hline
\end{tabular}

\section{RADIONUCLIDE CONCENTRATIONS ON AIRBORNE AND GROUND SOLIDS}

Identification of relationships between radionuclide concentrations on airborne solids and contaminated ground solids would be useful in establishing criteria for releasing contaminated areas for other uses. Concentrations on ground surfaces obtained from the literature $(4,20,23)$ are shown in Table 3 for ${ }^{137} \mathrm{Cs}$ and ${ }^{239} \mathrm{Pu}$ in $\mu \mathrm{Ci} / \mathrm{g}$ of solids. The ${ }^{137} \mathrm{Cs}$ concentrations ranged from $3 \times 10^{-8}$ to $2.5 \times 10^{-2} \mu \mathrm{Ci} / \mathrm{g}$. The range for ${ }^{239} \mathrm{Pu}$ was from less than radiochemical detection limits to $6.9 \times 10^{-7}$ $\mu \mathrm{Ci} / \mathrm{g}$ of surface solids. The maximum reported ${ }^{239} \mathrm{Pu}$ concentrations for surface solids were within the 200 areas. The minimum ${ }^{239} \mathrm{Pu}$ concentrations on surface solids reported ${ }^{(20)}$ in the literature occurred at 19 to $34 \mathrm{~km}$ from Hanford. Surface contamination levels were reported only out to $34 \mathrm{~km}$. These contamination levels are used in Table 3.

Table 4 is a summary of airborne solids concentrations in $\mu \mathrm{Ci} / \mathrm{g}$ for ${ }^{239} \mathrm{Pu},{ }^{247} \mathrm{Am},{ }^{238} \mathrm{Pu}$, and ${ }^{137} \mathrm{Cs}$. These concentrations were obtained from Figures 5, 7, and 9. Table 4 also shows ground surface contaniination levels for ${ }^{239} \mathrm{Pu}$ and ${ }^{137} \mathrm{Cs}$, expressed in $\mu \mathrm{Ci} / \mathrm{g}$. From these, ratios of $\mu \mathrm{Ci} / \mathrm{g}$ of airborne solids to $\mu \mathrm{Ci} / \mathrm{g}$ of surface solids were determined. The last column shows maximum ratio ranges. Ratios vary from $10^{-3}$ to $8 \times 10^{3}$, indicating that contaniination levels on airborne solids can be either much less than or much greater than contamination levels on contaminated surface solids. This wide range of ratios may indicate the possibility of non-uniform surface contamination, of too few surface contamination levels 
TABLE 3. Concentrations of Radionuclides in Hanford Ground Surface Solid Samples Reported in the Literature

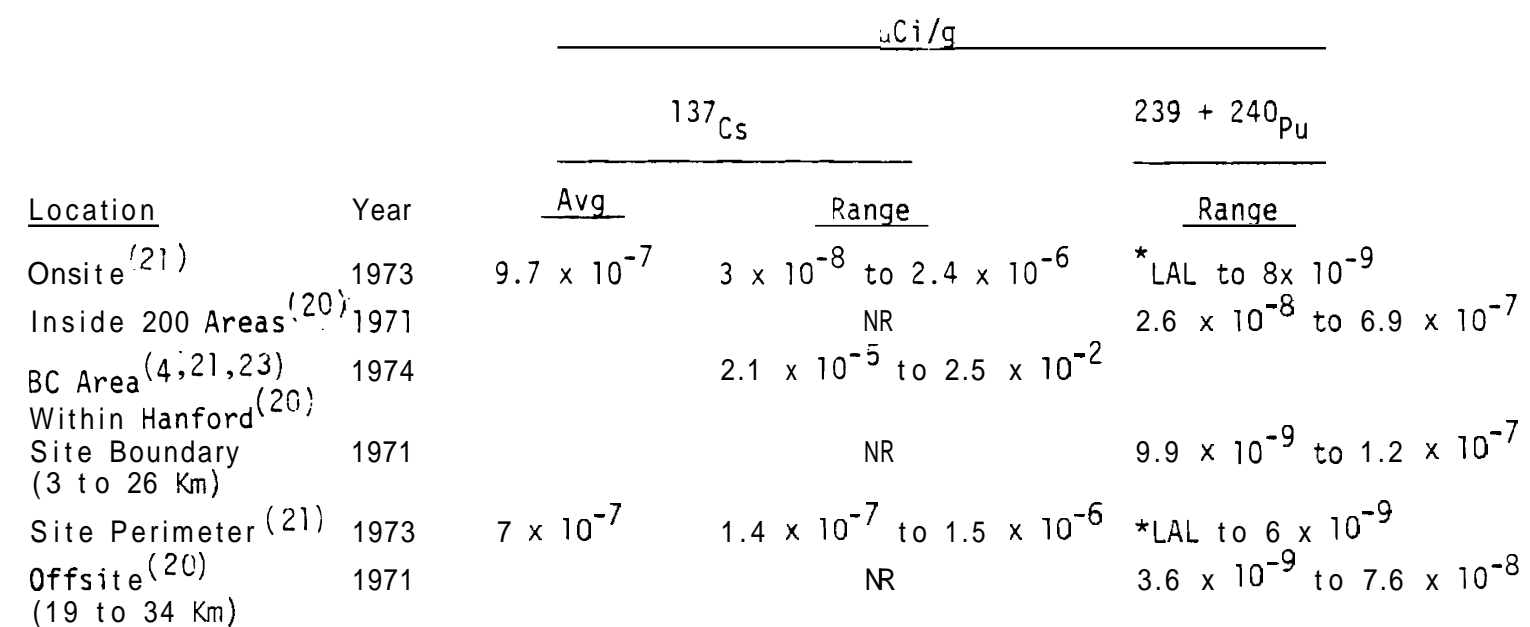

*LAL, less than analytical limit.

NR, not reported.

TABLE 4. Ratio of Airborne to Ground Surface Radionuclide Concentrations Per Gram of Solids

\begin{tabular}{|c|c|c|c|c|c|}
\hline Material & \multicolumn{4}{|c|}{ Concentration, $\mu \mathrm{Ci} / \mathrm{g}$ Solids } & $\begin{array}{c}\text { Maximum } \\
\text { Ratio Ranae, } \\
(\mu \mathrm{Ci} / \mathrm{g})_{\text {air }} \\
\frac{(\mu \mathrm{Ci} / \mathrm{g}) \stackrel{\star}{\text { surface }}}{}\end{array}$ \\
\hline & & & & & \\
\hline${ }^{239} \mathrm{Pu}$ & $2 \times 10^{-8}$ & $6 \times 10^{-5}$ & LAL & $8 \times 10^{-9}(20)$ & $2 \times 10^{\circ}$ to $8 \times 10^{3}$ \\
\hline${ }^{241}$ Am & $1 \times 10^{-7}$ & $7 \times 10^{-5}$ & NR & NR & \\
\hline${ }^{238} \mathrm{Pu}_{\mathrm{u}}$ & $1 \times 10^{-9}$ & $1 \times 10^{-6}$ & R & $\mathrm{NR}$ & \\
\hline${ }^{137} \mathrm{Cs}$ & $2 \times 10^{-5}$ & $1 \times 10^{-2}$ & NR & NR & \\
\hline $\begin{array}{l}{ }^{137} \text { Cs at } \\
B C-C r i b \text { Area } \\
10 \text { areas, }(24)\end{array}$ & $3 \times 10^{-5}$ & $7 \times 10^{-4}$ & & & \\
\hline $1 m^{2}$ & & & $2.1 \times 10^{-5}$ & $1.2 \times 10^{-3}$ & $\begin{array}{l}1 \times 10^{-3} \\
\text { to }\end{array}$ \\
\hline $\begin{array}{l}\text { Maximum report } \\
\text { value }(4)\end{array}$ & & & & $2.5 \times 10^{-2}$ & $3 \times 10^{7}$ \\
\hline
\end{tabular}

LAL- less than analytical limit.

$N R$ - Surface contamination levels not reported for all areas. If available, data for each area reported separately.

* Ratios from positive reported ground contamination values. 
reported in the literature, and/or transport of contaminated soils from upwind which may have either higher or lower concentrations than local surface soils.

Caution should be used in interpreting these data. The ground surface contamination data are limited in quantity and were not necessarily obtained in the same areas where resuspension experiments were performed. Airborne particle and ground contamination levels are shown for BC-Crib area in the last two columns of Table 4. In this case, BC-Crib area was sampled (24) in ten $1-m^{2}$ areas. Data from these ten squares indicated surface contamination levels varied by about a factor of 100 . Ratio ranges calculated from these data may be more representative than ranges calculated for ${ }^{239} \mathrm{Pu}$. The ${ }^{137} \mathrm{Cs}$ data for BC-Crib area ranges from $10^{-2}$ to 30 . The magnitude of this range is important, since one might as a first approximation assume air contamination levels per gram of solids to be equal to surface contamination levels per gram of solids. The potential fallacy of using such an assumption will be described later in this report.

\section{RESUSPENSION FACTORS}

Resuspension factors have been used in the literature to describe resuspension air concentrations. The resuspension factor (expressed in a unit of $\mathrm{m}^{-1}$ ) is defined as the airborne concentration of contaminant per cubic meter divided by the surface contamination level per square meter immediately below the point where the airborne concentration was measured. Often air concentrations for determining resuspension factors have been measured from about 1 to $1-1 / 2 \mathrm{~m}$ above ground. However, airborne concentrations are a function of the upwind contamination level, not a contamination level immediately below the air concentration measurement site. It is the transport from upwind contamination sites to the concentration measurement site that deterniines the airborne concentration.

Although the validity of resuspension factors is questionable, they were for a long time the only method for estimating air concentrations. Consequently resuspension factors were estimated from data obtained in this study. Resuspension factors and the basis for their calculation are 
shown in Table 5 for ${ }^{137} \mathrm{Cs}$ and ${ }^{239} \mathrm{Pu}$; literature values are used as an indication of ground surface contamination levels in $\mu \mathrm{Ci} / \mathrm{m}^{2}$, while airborne concentrations are the ones shown in Figures 4 and 6 . Resuspension factors calculated from air concentrations and ground surface contamination levels are shown in the last column. Resuspension factors for ${ }^{137} \mathrm{Cs}$ range from $4 \times 10^{-11}$ to $7 \times 10^{-8} \mathrm{~m}^{-1}$. Resuspension factors for ${ }^{239} \mathrm{Pu}$ range from $6 \times 10^{-10}$ to $2 \times 10^{-5} \mathrm{~m}^{-1}$. These ranges from $10^{-11}$ to $10^{-5} \mathrm{~m}^{-1}$ are within ranges reported in the literature.

\section{TABLE 5. Resuspension Factors}

\begin{tabular}{|c|c|c|c|c|c|c|}
\hline \multirow[b]{2}{*}{ Material } & \multirow[b]{2}{*}{ Area } & \multicolumn{2}{|c|}{$\begin{array}{c}\quad \begin{array}{c}x \\
\text { Air Concentration } \\
\mu C \mathbf{i} / \mathrm{cm}^{3}\end{array} \\
\end{array}$} & \multicolumn{2}{|c|}{$\begin{array}{c}\mathrm{G}, \\
\text { Surface }{ }^{\text {Contamination }} \\
\mu \mathrm{C} \mathbf{i} / \mathrm{m}^{2}\end{array}$} & \multirow{2}{*}{$\begin{array}{c}\text { Resuspension } \\
\text { Factor } \\
\mathrm{m}^{*}-1 \\
\end{array}$} \\
\hline & & $\underline{\text { Minimum }}$ & Maximum & Minimum & Maximum & \\
\hline${ }^{137} \mathrm{Cs}$ & $\mathrm{BC}(8,24)$ & $2 \times 10^{-15}$ & $2 \times 10^{-14}$ & 0.29 & 55.4 & $4 \times 10^{-11}$ to $7 \times 10^{-8}$ \\
\hline${ }^{239} \mathrm{Pu}$ & $\begin{array}{l}\text { "Inside chemical } \\
\text { separation areas" (20) }\end{array}$ & $7 \times 10^{-18}$ & $8 \times 10^{-15}$ & $4.9 \times 10^{-4}$ & $1.2 \times 10^{-2}$ & $6 \times 10^{-10}$ to $2 \times 10^{-5}$ \\
\hline
\end{tabular}

*Resuspension factor $=\left(10^{6}\right)(x) / G$ 
PREDICIED AIRBORNE RADIONUCLIDE CONCENIRATIONS FROM AIRBORNE SOLIDS

Airborne concentrations can either be determined experimentally or calculated on the basis of simplifying assumptions. For example, one assumption is that radioactivity concentrations on airborne solids are equal to radioactivity per gram of ground surface contaminated solids. As was shown in Table 4 for very limited data, this assumption is not always valid since the ratio of radionuclide concentration per gram of airborne solids to the radionucl ide concentration per gram of surface sol ids ranged from $10^{-3}$ to $8 \times 10^{3}$. Nevertheless, an equality assumption is used in this section to predict airborne radionuclide concentrations.

Airborne sol ids concentration levels were estimated from data(25) shown in Figure 10. Airborne particle volume distributions were determined on the Hanford Reservation using both an optical particle counter and a cowl-impactor system. ${ }^{(26)}$ The range obtained with the optical particle counter is shown as a cross-hatched area. Based upon measurements to now, the cowl impactor data shown have an upper limit, increasing with wind speed and decreasing height, (the April 1972 data) and a lower limit for other test periods indicated by the lines described by $3.460^{0.12}$ and $11600^{-1.48}$ To determine maximum airborne mass loadings, the upper or maximum limits of the curves for any particle diameter were integrated as a function of particle diameter. The lower limits were also integrated as a function of particle diameter. These integrations predict the solids mass loading per unit volume of air (shown in Table 6) as a function of four different particle diameter ranges: 0.16 to $1 \mu \mathrm{m}, 1$ to $10 \mu \mathrm{m}, 10$ to $100 \mu \mathrm{m}$, and 100 to $230 \mu \mathrm{m}$.

Particles less than $10 \mu \mathrm{m}$ diameter are frequently considered respirable (i.e., small enough to be inhaled into the lungs), even though $3.5 \mu \mathrm{m}$ appears to be more exact. In the following discussion, particles with diameters.less than $10 \mu \mathrm{m}$ are considered respirable and those larger than $10 \mu \mathrm{m}$ are nonrespirable. 
Neg. No. PNL 765836-1

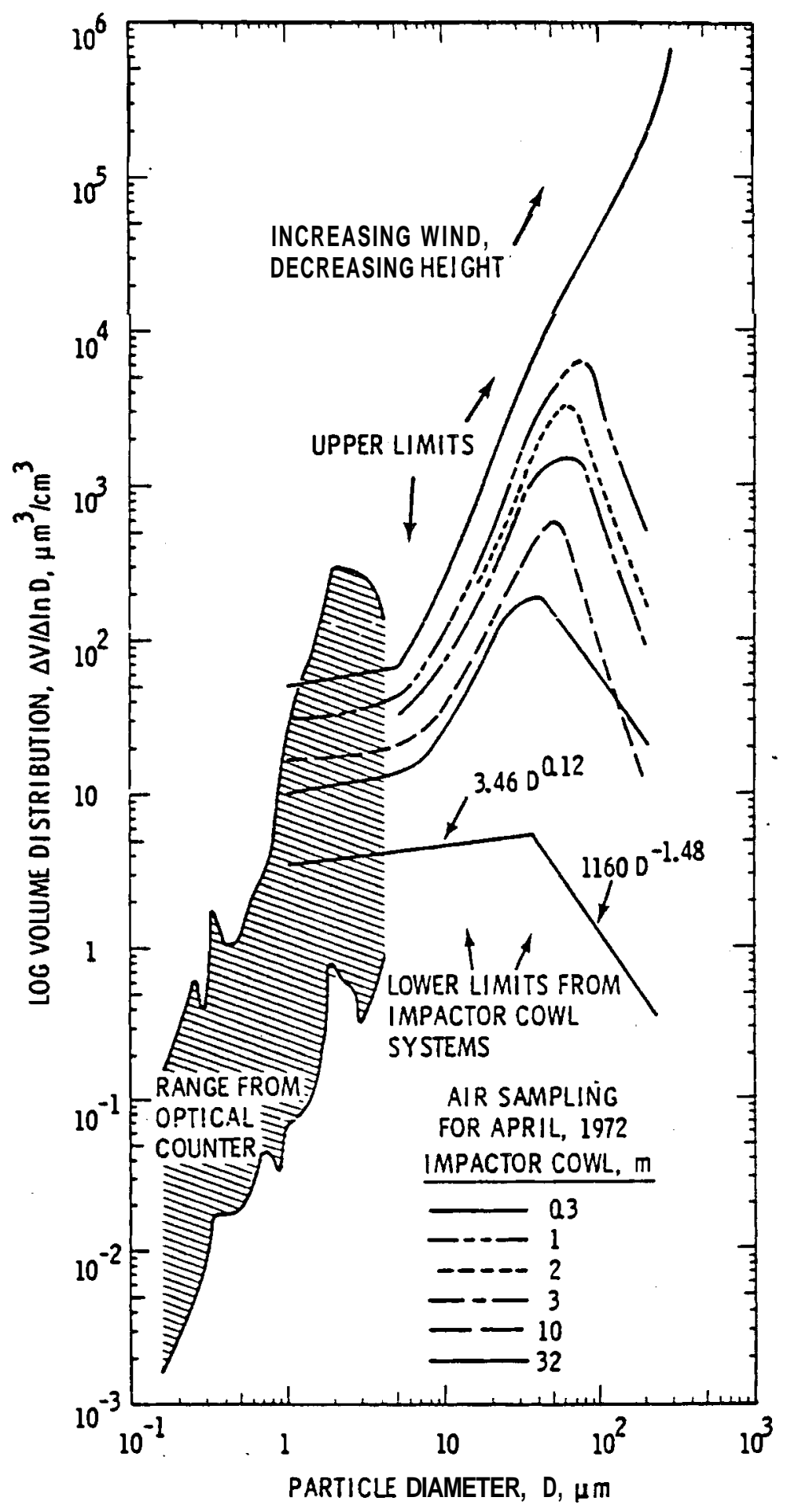

FIGURE 10. Airborne Particle Volume Distribution 


\section{TABLE 6. Calculated Airborne Concentrations From Airborne Solids Concentrations and Surface Contamination}

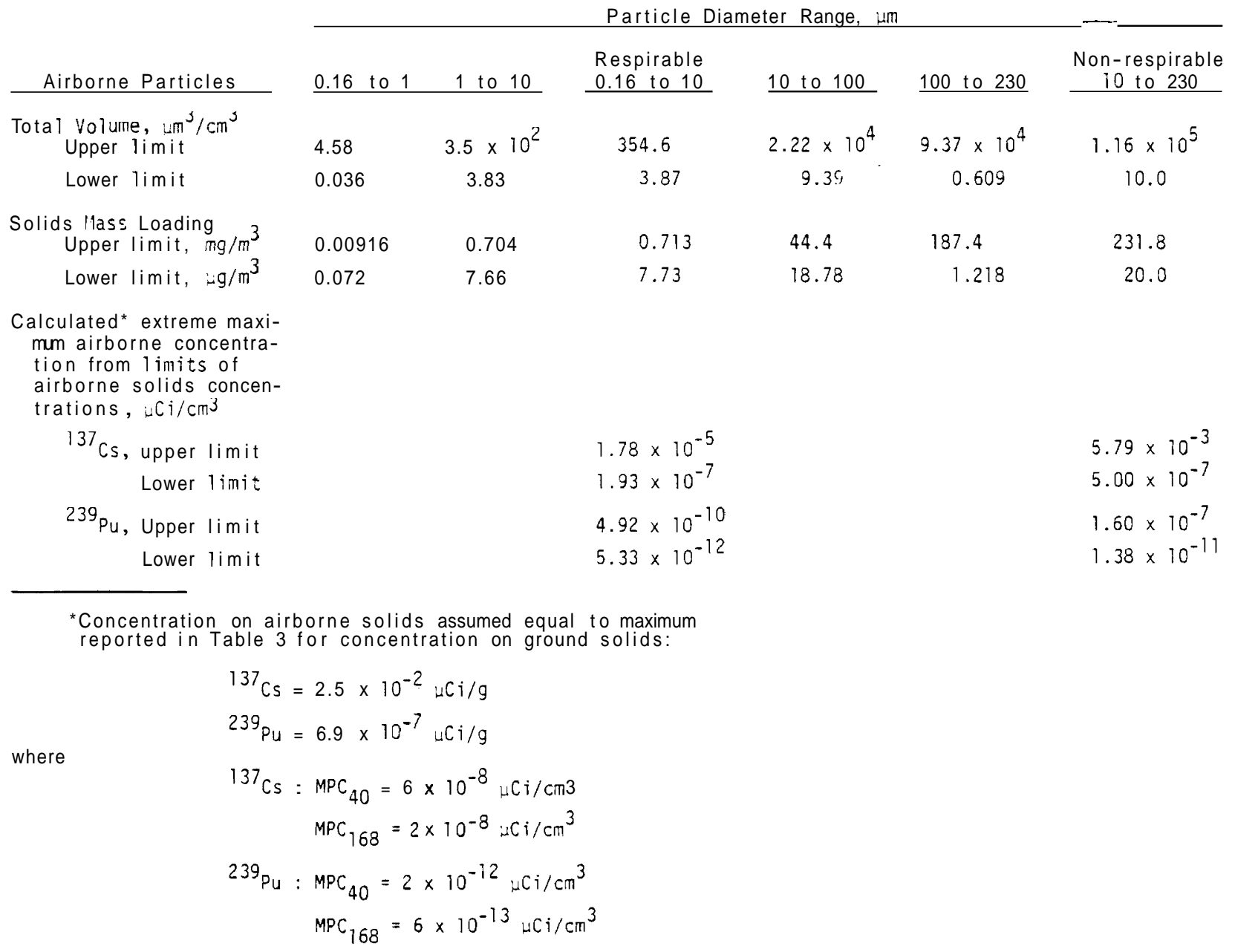


Mass loadings in these respirable and nonrespirable ranges are shown as upper limits of $0.7 \mathrm{mg} / \mathrm{m}^{3}$ for respirable particles and $231.8 \mathrm{mg} / \mathrm{m}^{3}$ for nonrespirable particles. The lower limits are $7.7 \mu \mathrm{g} / \mathrm{m}^{3}$ for respirable particles and $20 \mu \mathrm{g} / \mathrm{m}^{3}$ for nonrespirable particles. These mass loadings were multiplied by maximum surface contamination levels for ${ }^{137} \mathrm{Cs}$ and ${ }^{239} \mathrm{Pu}$ shown in Table 3. This approach yielded a predicted maximum airborne ${ }^{137} \mathrm{Cs}$ concentration for respirable particles of $1.78 \times 10^{-5} \mu \mathrm{Ci} / \mathrm{cm}^{3}$ and a predicted lower 7 imit of $1.93 \times 10^{-7} \mathrm{\mu Ci} / \mathrm{cm}^{3}$.

Upper and lower limits of ${ }^{239} \mathrm{Pu}$ concentrations on respirable and nonrespirable particles were calculated similarly. However, a comparison of airborne ${ }^{137} \mathrm{Cs}$ and ${ }^{239} \mathrm{Pu}$ concentrations predicted by this method and measured airborne concentrations (Figures 4 and 6) indicates the shortcomings of this calculational approach. This method predicts air concentrations could exceed MPC values. In contrast, average measured concentrations were less than $4 \times 10^{-3}$ of $\mathrm{MPC}_{4}-\mathrm{hr}$.

This airborne particle mass loading approach to calculate airborne radionuclide concentrations does not distinguish the sources of airborne material. For simple wind resuspension, airborne solids included contaminated solids (lower or higher radionuclide concentrations per gram of solid) blown in from the surrounding area as well as solids resuspended from the prime resuspension study site. In contrast, airborne solids above a mechanically disturbed area would be resuspended from the study site. In this case, possibly such an equality assumption of radionuclide concentration per gram of solids would be appropriate for mechanical disturbances $(28)$ of contaminated soil area.

Data are needed to determine resuspension rates and airborne concentration caused by mechanical resuspension. Airborne concentration levels from small local mechanical resuspension sites are expected to be greater than from wind stresses. 


\section{RESUSPENSION RHEASE HUXES}

An attempt was made (Table 7) to estimate the annual resuspension release fluxes of ${ }^{239} \mathrm{Pu},{ }^{238} \mathrm{Pu},{ }^{241} \mathrm{Am}$, and ${ }^{137} \mathrm{Cs}$ a t resuspension sites studied. The bases of this calculation are shown in the lower portion of Table 7. An average yearly wind speed ${ }^{(29)}$ of $3.4 \mathrm{~m} / \mathrm{sec}$ was assumed to transport airborne radioncutide through an area $30 \mathrm{~m}$ high and $150 \mathrm{~m}$ wide, giving $4.9 \times 10^{11} \mathrm{~m}^{3} /$ year flowing through this cross-sectional area. This air volume was multiplied by the maximum air concentrations shown in Figures 4, 6, and 8. Maximum rather than average airborne concentrations were used to provide ultraconservative estimations of downwind transport. On the basis of these calculations, maximum release rates ranged from 0.004 to $0.15 \mathrm{Ci} / \mathrm{yr}$. These are very small values. If the cross-sectional area were assumed to be much larger or smaller, maximum release fluxes would be correspondingly increased or decreased from these calculated values. However, in all cases average fluxes would be less than these maximum calculated fluxes.

\section{TABLE 7. Estimated Annual Resuspension Release Fl uxes}

\begin{tabular}{|c|c|c|}
\hline al & $\begin{array}{l}\text { Maximum Air } \\
\text { Concentration, } \\
\mu \mathrm{Ci}^{\mathrm{i}} / \mathrm{cm}^{3} \\
\end{array}$ & $\begin{array}{l}\text { Released for Assumed } \\
\text { Conditions, } \\
\text { Ci/yr }\end{array}$ \\
\hline${ }^{239} \mathrm{Pu}_{\mathrm{u}}$ & $8 \times 10^{-15}$ & 0.004 \\
\hline${ }^{24} 1_{\mathrm{Am}}$ & $3 \times 10^{-15}$ & 0.001 \\
\hline $238_{\mathrm{Pu}}$ & $8 \times 10^{-16}$ & 0.0004 \\
\hline & $3 \times 10^{-13}$ & 0.15 \\
\hline
\end{tabular}

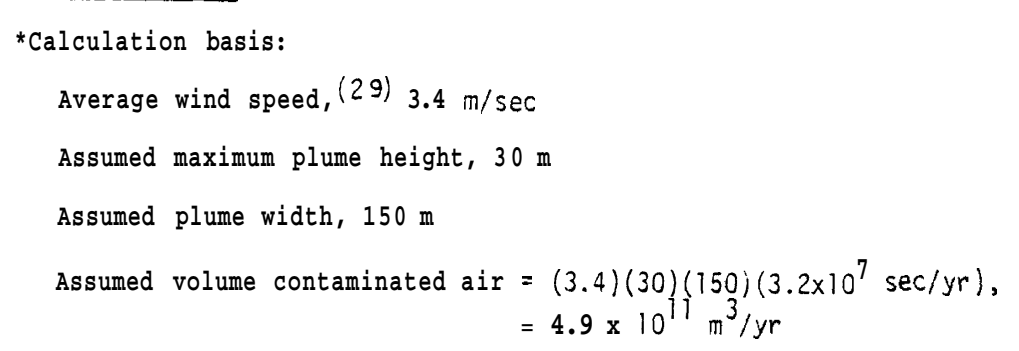




\section{SUGGESTHD FUTURE RESEARCH}

Several potentially valuable research areas are indicated by results of this study. A vital need is for model validation to predict transport from either wind-caused or mechanically-caused resuspension. Without additional resuspension data from surface contaminated areas, realistic predictions of local and downwind airborne hazards cannot be made. Predictions of resuspension as a function of particle size, surface properties, or time since material was deposited on the ground are especially inadequate. Although reported airborne concentrations have been below MPC, most air sampling devices are biased toward sampling respirable-sized particles. Information is needed on airborne radionucl ide concentrations and transport of nonrespirable-size particles.

In the tests reported here, airborne radionuclide concentrations increased as a function of wind speed west of U-Pond. However, air was sampled only when wind was blowing from the west toward U-Pond, and this air should not have passed over much surface-contaminated ground. Nevertheless, airborne concentrations did increase with the 1.0 to 1.5 power of wind speed. The resuspension source for these airborne radionuclides located much further upwind west of U-Pond in order to locate this resuspension source.

If fallout concentrations were simultaneously measured on the Arid Land Ecology (ALE) project on Rattlesnake Mountain as well as at several sites across the Hanford Reservation, the buildup of airborne concentration from local sources could be unequivocably shown. Air samplers could be activated as a function of wind direction and speed only when wind is blowing toward U-Pond from ALE land in the west.

Additional resuspension research in the S-16 area is also needed. This area was covered with dirt in the spring of 1975 . Resuspension research should be done around this area again to show whether radionuclide resus pension from this area has decreased. This would be the first experimental evidence that airborne radionuclide concentrations had decreased following dirt coverup. 
Surface contamination can either be covered up or cleaned up. Use of upwind and downwind air sampling towers around areas being considered for cleanup would be useful to determine the extent of cleanup operations which should be reasonably performed. If airborne concentrations blowing into the proposed cleanup area were comparable to airborne concentrations downwind, there could be some question as to whether cleanup operations would significantly decrease any airborne radiological hazard. In addition, airborne concentration may indicate that cleanup operation should be at some upwind site for which cleanup is more important than the site initially proposed for cleanup.

This report does not address the effects of mechanically-caused resuspension; only wind-caused resuspension is considered. The total release flux caused by wind resuspension from a large contaminated area may be significant. However, mechanical resuspension from a localized source could cause a much higher local airborne concentration than would simple wind resuspension. Mechanical resuspension releases large quantities of soil and solids into the air. For instance, most people have seen dust clouds around operating tractors. Effects of such mechanical resuspension should be considered in future research plans. While we know that wind will cause resuspension, we do not know the effects of future possible mechanical operations in surface-contaminated area. If surface-contaminated areas were released to the public for farming or habitation, mechanical resuspension and consequent inhalation would undoubtediy be the limiting hazard to people.

Transport of locally resuspended radionuclides can be described by meteorological transport and diffusion equations if resuspension rates and deposition velocities are available. Data from a local resuspension site have been used to predict airborne radionuclide concentrations at the Hanford Reservation boundary. ${ }^{(30)}$ Measurements should be made to validate model predictions and directly assess the effects of resuspension at the boundary measurement site. In this case, air concentrations would be sampled only when wind was blowing from the plant toward the air samplers. Similarly, air samplers would collect radioactive material when wind was blowing from offsite directions toward the plant. Comparisons of concentra 
tions from these two sets of air samplers would indicate whether airborne effects of resuspension sites are measurable at the Hanford Reservation boundary. 


\section{REFERENCES}

1. Pacific Northwest Laboratory Monthly Reports to ERDA, BNWL-1880, pp. 6-7, October 1974; BWNL-1868, p. 7, September 1974; BWNL-1844, p. 11, June 1974; BWNL-1814, pp. 18-20, January 1974; BWNL-1808, pp. 14-15, December 1973; BWNL-1802, pp. 10-11, November 1973; BWNL-1799, p. 12, October 1973; BWNL-1792, p. 12, September 1973. Battelle, Pacific Northwest Laboratories, Richland, WA 99352.

2. Recommendations of the International Commission on Radiological Protection, ICRP Publication 2, Report of Committee II on Permissible Dose for Internal Radiation, Pergamon Press, New York, NY, 1959.

3. G. A. Sehmel and F. D. Lloyd, "Wind-caused Particle Resuspension Rates. "In: Pacific Northwest Laboratory Annual Report for 1976, BNWL-2100-3, Battelle, Pacific Northwest Laboratories, Richland, 99352, 1977, in press.

4. H. L. Maxfield, A Preliminary Safety Analysis of the B-C Cribs Controlled Zone. ARH-3088, Atlantic Richfield Hanford Company, Richland, WA 99352, Appendix B-4, July 1974.

5. R. M. Emery and D. C. Klopfer, The Ecological Behavior of Plutonium and Americium in a Freshwater Ecosystem: Phase I - BWNL-1867, Battelle, Pacific Northwest Laboratories, Richland, WA 99352, 1974.

6. J. D. Anderson, Radioactive Liquid Wastes Discharged to Ground in the 200 Areas During 1972. ARH-2757, Atlantic Richfield Hanford Co., Richland, WA, 99352, 1973.

7. G. L. Hanson, J. D. Anderson, G. R. Kiel, B. J. McMurray, and N. P. Nisick, Input and Decayed Values of Radioactive Liquid Wastes Discharged to the Ground in the 200 Areas Through 1971. ARH-2761, Atlantic Richfield Hanford Co., Richland, WA, 99352, 1973.

8. L. E. Bruns, "Aerial Gamma Survey by Helicopter to Measure Surficial Contamination." In: Atmosphere-Surface Exchange of Particulate and Gaseous Pollutants, CONF-740921, National Technical Information Service, Springfield, VA 22151, pp. 675-688, January 1976.

9. T. T. O'Farrell and R. 0. Gilbert, "Transport of Radioactive Materials by Jackrabbits on the Hanford Reservation." Health'Physics 29:9-15, 1975.

10. T. T. O'Farrell and R. 0. Gilbert, Transport of Radioactive Wastes by Jackrabbits on the Hanford Reservation, BNWL-SA-5046, Battelle, Pacific Northwest Laboratories, Richland, WA, 99352, July 1974.

11. G. A Sehme], "An Evaluation of a Hiah-Volume Cascade Particle Impactor System." Proceedings of the Second joint Conference on Sensing of Environmental Pollutants, Washington, DC, December 10-12, 1973, Instrument Soc. of Amer., pp. 109-115, 1973. 
12. G. A. Sehmel and F. D. Lloyd, "Soil Resuspension by Saltation." In: Pacific Northwest Laboratory Annual Report for 1971, BWNL-1651-1, Battelle, Pacific Northwest Laboratories, Richland, WA 99352, pp. 141-143, 1972.

13. W. H. Zimmer, Automatic Radioactive Inventory System. ARH-SA-134, Atlantic Richfield Hanford Company, Richland, WA 99352, 1972.

14. N. A. Wogman, "An All Sodium lodide Anticoincidence Shielded Total Absorption Spectrometer for Low Level Radionuclide Analyses." Nuclear Instruments and Methods, 83:277-282, 1970.

15. J. D. Cooper and R.W. Perkins, A Versatile Ge (Li-NaI) Coincidence Anti-Coincidence Gamma-Ray Spectrometer for Environmental and Biologic al Problems. BWNL-SA-3972, Battelle, Pacific Northwest Laboratories, Richland, WA 99352, August 1971.

16. C. W. Thomas, "Atmospheric Fallout Durina 1975 at Richland, Washinaton and Point Barrow, Alaska." In: Pacific Northwest Laboratory Annual Report for 1975, BNWL-2000-3, Battelle, Pacific Northwest Laboratories, Richland, IA 99352, pp. 16-19, 1976.

17. C. W. Thomas, Battelle, Pacific Northwest Laboratories, Richland, WA, private communication, March-June 1976.

12. R. H. Wilson, R. G. Thomas and J. N. Stannard, Biomedical and Aerosol Studies Associated with a Field Release of Plutonium. WT-1511, Sandia Corporation, Albuquerque, NM, 1961.

19. G. A. Sehmel and F. .D. Lloyd, "Resuspension of Plutonium at Rocky Flats." In: Atrnosphere-Surface Exchange of Particulate and Gaseous Pollutants, CONF-740921, National Technical Information Service, Springfield, VA 22151, pp. 757-779, January 1976.

20. J. P. Corley, D. M. Robertson and F. P. Brauer, "Plutonium in Surface Soil in the Hanford Plant Environs." Proceedings of Environmental Plutonium Symposium, LA-4756, Los Alamos, NM, August 4-5, 1971, pp. 85-92, 1971.

21. W. L. Nees and J. P. Corley, Environmental Status of the Hanford Reservation for CY-1973. BNWL-B-336, Battelle, Pacific Northwest Laboratories, Richland, WA 99352, p. 49, January 1975.

22. J. Mishima and L. C. Schwendiman. "Potential Airborne Release of Surface Contamination During a Range Fire." In: Pacific Northwest Laboratory Monthly Activities Report January 1974, BNWL-1814, p. 18, 1974.

23. J. Mishima and L. C. Schwendiman, "Potential Airborne Release of Cs-137 Activity During a Range Fire in the B-C Controlled Area." In: Pacific Northwest Laboratory Monthly Activities Report October 1973, BWNL-1799, p. $10,1973$. 
24. J. Mishima, "Distribution of Cs-137 Activity During a Range Fire in the B-C-Controlled Area." In: Pacific Northwest Laboratory Monthly Activities Report September 1973, BNWL-1792, p. 13, 1973.

25. G. A. Sehmel, "The Influence of Soil Insertion on Atmospheric Particle Size Distributions." In: Pacific Northwest Laboratory Annual Report for 1975, BNWL-2000-3, B attelle, Pacific Northwest Laboratories, Richland, WA 99352, pp. 99-101, 1976.

26. G. A. Sehmel and F. D. Lloyd, "Particle Resuspension Rates." In: Atmosphere-Surface Exchange of Particulate and Gaseous Pollutants, CONF-740921, National Technical Information Service, Springfield, VA 22151 , pp. 846-858, January 1976.

27. G. A. Sehmel, "Particle Resuspension from an Asphalt Road Caused by Car and Truck Traffic." Atmospheric Environment, I:291-301, 1973.

28. R. C. Milham, J. F. Schubert, J. R. Watts, A. L. Boni and J. C. Corey, "Measured Plutonium Resuspension and Resulting Dose from Agricultural Operations on an Old Field at the Savannah River Plant in the SouthEastern United States of America," Transuranium Nuclides in the Environment. International Atomic Energy Agency, Vienna, Austria, pp. 409-421, 1976.

29. W. A. Stone, D. E. Jenne and J. M. Thorp, Climatography of the Hanford Area. BNWL-1605, Battelle, Pacific Northwest Laboratories, Richland, WA 99352, p. 5.9, 1972.

30. T. W. Horst, The Estimation of Air Concentrations Due to the Suspension of Surface Contamination by the Wind. BNWL-2047, Battelle, Pacific Northwest Laboratories, Richland, WA, 99352, March 1976. 


\section{DISTRIBUTION}

No. of

$\underline{\text { Copies }}$

\section{OFFSITE}

A. A. Churm

ERDA Chicago Patent Group

9800 South Cass Avenue

Argonne, IL 60439

D. H. Slade

ERDA Division of Biomedical and Environmental Research

Washington, DC 20545

R. W. Beadle

ERDA Division of Biomedical and Environmental Research

Washington, DC 20545

N. F. Barr

ERDA Division of Biomedical and Environmental Research

Washington, DC 20545

D. S. Ballantine

ERDA Division of Biomedical and Environmental Research

Washington, DC 20545

R. W. Elliot

ERDA Division of Biomedical and Environmental Research

Washington, DC 20545

J. L. Liverman

ERDA Division of Biomedical and Environmental Research

Washington, DC 20545

H. Moses

ERDA Division of Biomedical and Environmental Research

Washington, DC 20545

B. W. Wachholz

ERDA Division of Biomedical and Environmental Research

Washington, DC 20545
No. of

Copies

F. P. Baranowski

ERDA Division of Nuclear Fuel Cycle and Production

Washington, DC 20545

W. K. Eister

ERDA Division of Nuclear Fuel Cycle and Production

Washington, DC 20545

Charles Sherman

ERDA Headquarters Library

J. J. Davis

NRC, Division of Research

Washington, D 20545

H. Landon

NRC, Division of Research

Washington, D 20545

M. R. Biles

ERDA, Division of Operational Safety

Washington, DC 20545

A. A. Schoen

ERDA, Division of Operational Safety

Washington, D 20545

Gordon Facer

ERDA, Division of Military

Application

Washington, DC 20545

J. W. Healy

Los Alamos Scientific

Laboratory of the

University of California

Los Alamos, NM 87544 
No. of

Copies

J. R. Travis
Los Alamos Scientific Laboratory of the University of California
Los Alamos, NM 87544

M. A. Thompson

Rockwe11 International

Atomics International Division

Rocky Flats Plant

P.0. Box 464

Golden, Co 80401

R. 0. Williams, Jr. Rockwel1 International Atomics International Division

Rocky Flats Plant

P.0. Box 464

Golden, C0 80401

D. A. Wiederecht

Rockwell International

Atomics International

Division

Rocky Flats Plant

P.0. Box 464

Golden, C0 80401

W. P. Wood

EPA, AW \#460

Office of Radiation

Programs

Washington, DC 20460

27 ERDA Technical Information Center
No. of

Copies

ONSITE

8 ERDA Richland Operations Office

P. F. X. Dunigan

0. J. Elgert

R. B. Goranson

P. G. Holsted

N. T. Karagianes

P. G. Rhoades

M. W. Tiernan

W. Lei

H. E. Ransom

16 Atlantic Richfield Hanford Company

D. J. Brown

L. E. Bruns

R. D. Fox (10)

M. W. Legatski

B. J. McMurray

J. B. Panesko

W. H. Price

50 Battelle, Pacific Northwest Laboratcries

W. J. Bair

R. L. Conley

J. P. Corley

D. K. Craig

R. L. Drake

C. E. Elderkin

R. M. Emery

L. Faust

J. J. Fuquay

R. 0. Gilbert

J. M. Hales

J. Mishima

M. M. Orgi11

L. C. Schwendiman (4)

G. A. Sehmel (25)

C. I. Simpson

R. C. Thompson

D. L. Hessel

L. L. Wendell

Tech. Information Library (3)

Tech. Publications 